\title{
New insights into the petrogenesis of the Jameson Range layered intrusion and associated Fe-Ti-P-V-PGE-Au mineralisation, West Musgrave Province, Western Australia
}

\author{
Bartosz T. Karykowski ${ }^{1,2}$ • Paul A. Polito ${ }^{3}$ - Wolfgang D. Maier ${ }^{1}$. Jens Gutzmer ${ }^{2,4}$. \\ Joachim Krause $^{4}$
}

Received: 29 June 2015 / Accepted: 31 March 2016 / Published online: 10 May 2016

(C) The Author(s) 2016. This article is published with open access at Springerlink.com

\begin{abstract}
The Mesoproterozoic Jameson Range intrusion forms part of the Giles Complex, Musgrave Province, Western Australia. It is predominantly mafic in composition comprising olivine-bearing gabbroic lithologies with variable amounts of magnetite and ilmenite. Lithologies containing more than 50 vol\% magnetite and ilmenite are classified as magnetitites. The Jameson Range hosts several of these magnetitites forming laterally extensive layers, which can be traced for at least $19 \mathrm{~km}$ as continuous magnetic anomalies. Similar occurrences of magnetitites are known from the upper parts of other layered intrusions, such as the Bushveld Complex. In addition, the intrusion hosts several P-rich zones, one of which is at least $59 \mathrm{~m}$ in thickness containing $1.0 \mathrm{wt} \%$ $\mathrm{P}_{2} \mathrm{O}_{5}$. The P-rich zones are not directly associated with the magnetitites, but they mostly occur slightly above them. The mineral chemistry of the Jameson Range cumulates is
\end{abstract}

Editorial handling: M. Fiorentini

Electronic supplementary material The online version of this article (doi:10.1007/s00126-016-0655-y) contains supplementary material, which is available to authorized users.

Bartosz T. Karykowski

bkarykowski@yahoo.com

1 School of Earth and Ocean Sciences, Cardiff University, Main Building, Park Place, Cardiff CF10 3AT, UK

2 Institut für Mineralogie, TU Bergakademie Freiberg, 09596 Freiberg, Germany

3 Anglo American Exploration (Australia) Pty Ltd, 245 Canning Hwy, Como, WA 6152, Australia

4 Helmholtz-Zentrum Dresden-Rossendorf, Helmholtz Institute Freiberg for Resource Technology, Halsbrücker Str. 34, 09599 Freiberg, Germany relatively evolved with olivine compositions ranging from $\mathrm{Fo}_{44}$ to $\mathrm{Fo}_{60}$ and plagioclase compositions varying between $\mathrm{An}_{56}$ and $\mathrm{An}_{59}$. The $\mathrm{Mg} \#(100 \times \mathrm{Mg} /(\mathrm{Mg}+\mathrm{Fe}))$ of ortho- and clinopyroxene ranges from 60 to 61 and from 70 to 75 , respectively. Magnetite compositions are characterised by low $\mathrm{TiO}_{2}$ concentrations varying from 0.39 to $3.04 \mathrm{wt} \%$ representing near end-member magnetite with up to $1.2 \mathrm{wt} \%$ $\mathrm{Cr}$ and $1.3 \mathrm{wt} \% \mathrm{~V}$, respectively. The basal magnetite layer reaches up to $68.8 \mathrm{wt} \% \mathrm{Fe}_{2} \mathrm{O}_{3}(\mathrm{t})$ and $24.2 \mathrm{wt} \% \mathrm{TiO}_{2}$, and it is also markedly enriched in $\mathrm{Cu}$ (up to $0.3 \mathrm{wt} \% \mathrm{Cu}$ ), $\mathrm{V}$ (up to $1.05 \mathrm{wt} \% \mathrm{~V}_{2} \mathrm{O}_{5}$ ) and platinum-group elements (PGE) (up to $2 \mathrm{ppm} \mathrm{Pt}+\mathrm{Pd}$ ). Sulphide minerals comprising bornite, chalcopyrite and minor pentlandite occur finely disseminated in the magnetitite and account for the elevated base metal and PGE concentrations. Modelling indicates that the PGE mineralisation was formed at very high $R$ factors of up to 100,000 , which is typical for PGE reefs in layered intrusions. Whole rock geochemical and mineralogical data of the magnetite layers and their host rocks further allow for a refinement of current formation models of layered igneous sequences. Several lines of evidence suggest that the magnetite layers formed in response to primarily density-controlled mineral sorting within crystal slurries, although the grain size also affects the sorting process.

Keywords Musgrave Province $\cdot$ Giles Complex $\cdot$ Layered intrusion · Platinum-group elements $\cdot$ Magnetite layers

\section{Introduction}

The Musgrave Province is a focal point of Mesoproterozoic mafic-ultramafic magmatism in central Australia. As a result, the region hosts one of the most extensive volumes of maficultramafic rocks on Earth, termed "Giles Complex" (Nesbitt 
and Talbot 1966) or "Giles Event" (Howard et al. 2011b). Large layered intrusions are known to contain several commodities of major economic interest, such as $\mathrm{Ti}, \mathrm{Cr}, \mathrm{V}, \mathrm{P}, \mathrm{Ni}$, $\mathrm{Cu}$ and platinum-group elements (e.g. Bushveld Complex). However, due to the remoteness of the area, the mineral potential and the formation of the Giles Complex remain poorly constrained. With the discovery of a large magmatic sulphide deposit at Nebo-Babel in 2000, several exploration companies became interested in the area. The main targets of exploration were magmatic $\mathrm{Ni}-\mathrm{Cu}$ sulphide deposits in magma conduits, whereas orthomagmatic $\mathrm{Fe}$, Ti, $\mathrm{Cr}, \mathrm{V}, \mathrm{P}$ and platinum-group element (PGE) mineralisation within the layered successions of the intrusions remained a subordinate target.

In this study, we report the firstly discovered occurrence of P-rich lithologies associated with layered mafic-ultramafic rocks in the Musgrave Province intersected by drill cores in the Jameson Range. We describe the petrography and present new compositional data of drill core samples from the PGErich magnetitites and its immediate host rocks. The data allow us to constrain the stratigraphy of the poorly exposed Jameson Range intrusion and to provide a better estimate on the thickness of the layered succession and its mineral potential.

\section{Previous work in the Musgrave Province}

Basic mapping and prospecting in the Musgrave Province began in the early 1950s, when exploration undertaken by Western Mining Corporation Ltd (WMC Resources) and South Western Mining Company Ltd resulted in the discovery of the Wingellina $\mathrm{Ni}$ laterite deposit in 1956. At the same time, Westfield Minerals Ltd targeted titanomagnetite layers in the Jameson Range. The first detailed geological map was produced by the Geological Survey of Western Australia (GSWA) following systematic mapping of the layered Giles Complex, including the Jameson Range, in the late 1960s (Daniels 1974). Petrogenetic studies were subsequently conducted by Nesbitt et al. (1970), Goode and Moore (1975) and others.

In the early 1970s, the Musgrave Province became part of the Central Aboriginal Reserve precluding exploration activities until 1995, when the first access agreements were reached with the Ngaanyatjarra Council representing the interests of the Traditional Owners. In 1987, the Australian Geological Survey Organisation (AGSO, now: Geoscience Australia) initiated the "Musgrave Project" resulting in a number of detailed petrological reports on the layered sequence (e.g. Ballhaus and Glikson 1995; Glikson et al. 1995; Glikson et al. 1996). On the basis of these studies, it was suggested that some of the Giles intrusions represent tectonically dismembered fragments of an initially contiguous intrusion, whereas most of the intrusions were derived from several chemically distinct parental magmas forming separate discontinuous intrusions (Ballhaus and Glikson 1995).

After 1995, a number of exploration companies gained interest in the area and collected extensive geochemical and geophysical data leading to the discovery of the magmatic $\mathrm{Ni}-\mathrm{Cu}$ sulphide deposit at Nebo-Babel in 2000 (Baker and Waugh 2005). The mineralised intrusion was studied in great detail by Seat et al. (2007), Seat et al. (2009), Godel et al. (2011) and Seat et al. (2011). From 2004, the GSWA mapped the West Musgrave Province on a 1:100,000 scale (Howard et al. 2011b). A comprehensive account of the petrogenetic aspects and the prospectivity of the Giles Complex was produced by Maier et al. $(2014,2015)$.

\section{Geological background}

\section{Regional geology}

The Musgrave Province represents an orogenic belt approx. $800 \mathrm{~km}$ long and $350 \mathrm{~km}$ wide with coherent geological and geophysical characteristics. It is situated at the intersection of the North Australian, the West Australian and the South Australian cratons (Fig. 1) (Howard et al. 2011b). As a result of its location, several major tectonic episodes affected the area producing a high-grade metamorphic basement of Paleoproterozoic age, which was intruded by voluminous, broadly coeval, mafic-ultramafic and felsic intrusions of the Warakurna Supersuite (Nesbitt et al. 1970; Myers et al. 1996; Smithies et al. 2008). Expressions of this bimodal magmatism occur throughout the western and central parts of Australia; however, in the Musgrave Province, this particular episode lasting from c. 1090 to $1040 \mathrm{Ma}$ is termed "Giles Event" (Wingate et al. 2004). It mainly comprises layered mafic-ultramafic intrusions (G1), slightly younger massive gabbro (G2) and the Alcurra Dolerite Suite postdating the G1 and G2 intrusions (Howard et al. 2009). The G1 intrusions account for most of the mafic-ultramafic magma volume produced during the Giles Event. However, the Alcurra Dolerite Suite hosts a number of recently discovered magmatic sulphide occurrences, such as Nebo-Babel (Seat et al. 2007), Manchego (Karykowski et al. 2015) and Halleys (Maier et al. 2015). Detailed reviews of the Musgrave Province including its mineral potential as well as its tectonic evolution are provided by Glikson et al. (1996), Smithies et al. (2008), Maier et al. (2015) and Howard et al. (2015). 


\section{Geology of the Jameson Range}

The troctolitic Jameson Range intrusion is one of the layered mafic-ultramafic intrusions of the Giles Event. The minimum age of the G1 intrusions is based on a U-Pb zircon age of 1078 \pm 3 Ma obtained from a granophyric leucogranite believed to form part of the layered sequence (Sun et al. 1996). Moreover, a direct $\mathrm{U}-\mathrm{Pb}$ zircon age of 1076 \pm 4 Ma was obtained from a G1 leucogabbro east of the Jameson Range (Kirkland et al. 2011). According to Maier et al. (2015), the Jameson Range represents the upper part of a tectonically dismembered portion of an originally contiguous body termed "Mantamaru Intrusion". Outcrop in the Jameson Range is generally poor with the basal and top contacts of the intrusion not being exposed. Magmatic layering dips at $20^{\circ}$ to $30^{\circ}$ to the southwest, and the layered succession is not overturned. The stratigraphic thickness has been estimated to be up to $10 \mathrm{~km}$ (Maier et al. 2014).

Daniels (1974) described four main lithological zones in the Jameson Range. These are from the base to the top: glomeroporphyritic gabbro (zone 1); banded lherzolite and Fe-Ti oxide-bearing lherzolite (zone 2); rhythmically layered troctolite and olivine-gabbronorite (zone 3); and layered troctolite, olivine-gabbro and olivine-gabbronorite with at least 11 titaniferous magnetite layers (zone 4). Maier et al. (2014) reported an enrichment of precious metals in the outcropping basal titaniferous magnetite layer reaching up to $2 \mathrm{ppm} \mathrm{Pt}+\mathrm{Pd}+\mathrm{Au}$, whereas magnetite layers in stratigraphically higher levels are barren. Notably, none of the Jameson Range samples from Maier et al. (2014) was reported to be enriched in phosphate $\left(\mathrm{P}_{2} \mathrm{O}_{5}\right)$. Some layers, especially the basal one, can be traced for at least $19 \mathrm{~km}$ as continuous magnetic anomalies with occasional outcrop (Fig. 2). Locally, the basal layer may develop up to three sub-layers for a combined thickness of up to $50 \mathrm{~m}$. Faulting also seems to be relatively common in the Jameson Range as indicated by major linear magnetic discontinuities, especially discernible along the strike of magnetite layers.

\section{Petrography}

The intersected portion of the Jameson Range intrusion mainly comprises leuco-olivine-gabbronorite, magnetitite, magnetite-gabbronorite, leuco-olivinegabbro as well as two types of dolerite dykes crosscutting the layered succession. The following petrographic descriptions are partly from Crawford (2012) complemented by our own observations. The rock types are classified following Le Maitre (2002) and described by descending frequency of occurrence.

\section{Leuco-olivine-gabbronorite}

The leuco-olivine-gabbronorite is a weakly layered, mediumgrained adcumulate with more than 65 vol.\% plagioclase. Plagioclase normally occurs as inequigranular aggregates of up to 4-mm-long prismatic crystals. Olivine accounts for 5 to $10 \mathrm{vol} \%$ (Fig. 3a) of the mode forming discontinuous schlieren of more than $10 \mathrm{~mm}$ in length. Individual olivine grains are mostly unaltered reaching up to $2 \mathrm{~mm}$ in diameter. Anhedral ortho- and clinopyroxene grains of up to $2 \mathrm{~mm}$ account for 5 to $10 \mathrm{vol} \%$, each. The Fe-Ti oxides are interstitial compound grains of up to $3 \mathrm{~mm}$ comprising homogenous ilmenite and titanomagnetite with fine ilmenite exsolution lamellae accounting for 5 to $10 \mathrm{vol} \%$.
Fig. 1 Simplified bedrock geology map of the eastern portion of the West Musgrave Province. The locations of diamond drill cores used in this study are shown as red circles. The areal extent of the Musgrave Province is outlined in the inset. Note the close proximity to the North, South and West Australian cratons. Modified from Howard et al. (2011a)

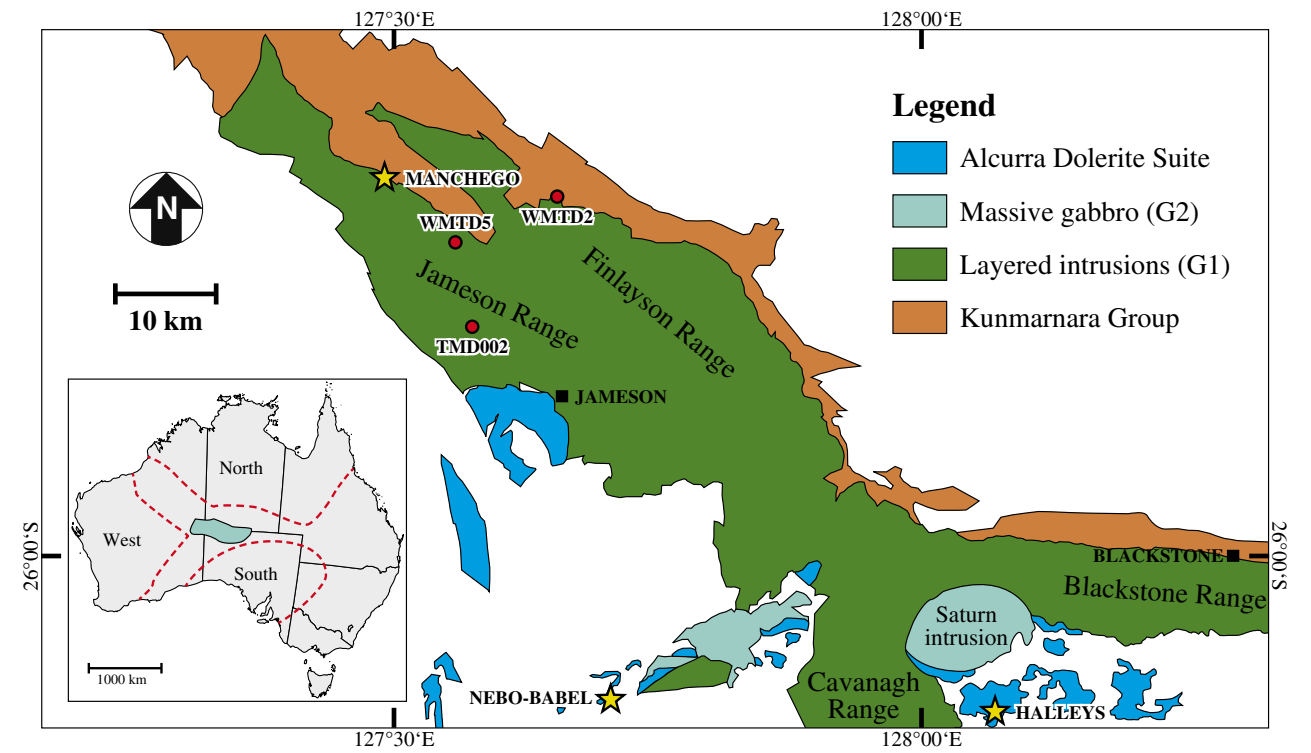




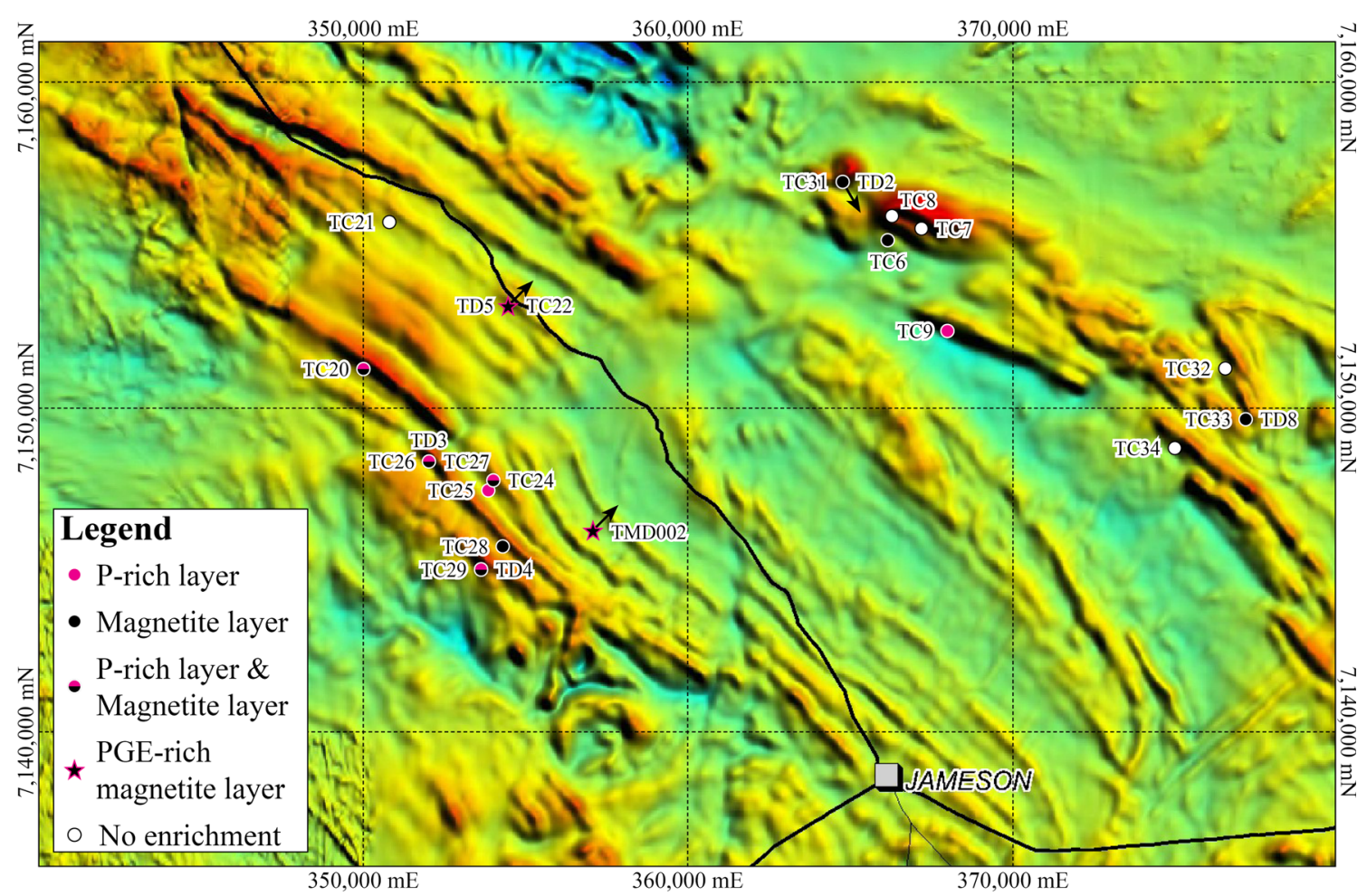

Fig. 2 Total magnetic intensity map showing the location of drill holes intersecting the Jameson Range. Note the distinct linear magnetic signature of the magnetitites in the western part. The magnetic signature in the eastern part is considerably more diffuse. Several tectonic

\section{Magnetitite}

All samples with $>50$ vol\% Fe-Ti oxides are classified as magnetitites. They occur in all three studied drill holes and consist of a network of intergrown granular polygonal-shaped grains of titanomagnetite and ilmenite forming triple junctions with $120^{\circ}$ interfacial angles (Fig. 3b). The base of the magnetite layers is usually characterised by a sharp contact, whereas the upper contact tends to be gradational. The oxide grains range from 0.5 to $5 \mathrm{~mm}$ in diameter accounting for 50 to 98 vol\% of the rock type. Generally, homogenous ilmenite is concentrated in discontinuous layers of individual crystals oriented sub-parallel to the magmatic layering, separated by thicker layers of equal-sized titanomagnetite (ESM 1: Fig. S1).

Silicates in the magnetitites from drill holes WMTD5 and TMD002 comprise olivine, plagioclase and minor clinopyroxene occurring as rounded, anhedral and partially resorbed crystals of less than $1 \mathrm{~mm}$ in size within a framework of Fe-Ti oxides. Automated MLA-XMOD measurements show that 96 to 98 vol\% of the basal magnetitite are composed of Fe-Ti oxides.

Notably, the only silicates in the magnetitite from drill hole WMTD2 are fractured and resorbed olivine with minor pyroxene, whereas plagioclase is entirely absent (Fig. 3c). The silicate crystals are generally spherical and vary in size from 1 to lineaments can also be inferred as major linear magnetic discontinuities. The black arrows indicate the dip direction of the diamond drill holes. Abbreviations: $T C=$ reverse circulation $(\mathrm{RC})$ drill holes; $T D=$ diamond drill holes. Modified from Geological Survey of Western Australia (2002)

$3 \mathrm{~mm}$. The Fe-Ti oxides are also significantly smaller compared to those from drill holes WMTD5 and TMD002. In contrast, homogenous ilmenite is more abundant in the magnetitite from WMTD2, with modal titanomagnetite/ ilmenite ratios ranging from 5:5 to $5.5: 4.5$ compared to $6: 4$ and 8:2 in the magnetitite from drill hole WMTD5.

\section{Magnetite-gabbronorite}

The magnetite-gabbronorite is a weakly layered, mediumgrained adcumulate with 30 to 45 vol\% Fe-Ti oxides and 30 to $35 \mathrm{vol} \%$ plagioclase. Ortho- and clinopyroxene account for 5 to 10 vol\% each, whereas olivine is slightly more abundant reaching up to 15 vol\%. The minerals generally occur as anhedral or subhedral grains reaching 2 to $3 \mathrm{~mm}$ across. The Fe-Ti oxides are interstitial to the silicate framework and comprise homogenous ilmenite as well as titanomagnetite showing fine ilmenite exsolution lamellae (Fig. 3d).

\section{Leuco-olivine-gabbro}

The leuco-olivine-gabbro is a weakly layered, mediumgrained rock type characterised by 70 to 80 vol\% subhedral prismatic plagioclase reaching 0.5 to $3 \mathrm{~mm}$ in length. Olivine and clinopyroxene occur in centimetre-long layers of several anhedral to subhedral grains of 0.5 to $1 \mathrm{~mm}$ in size accounting 

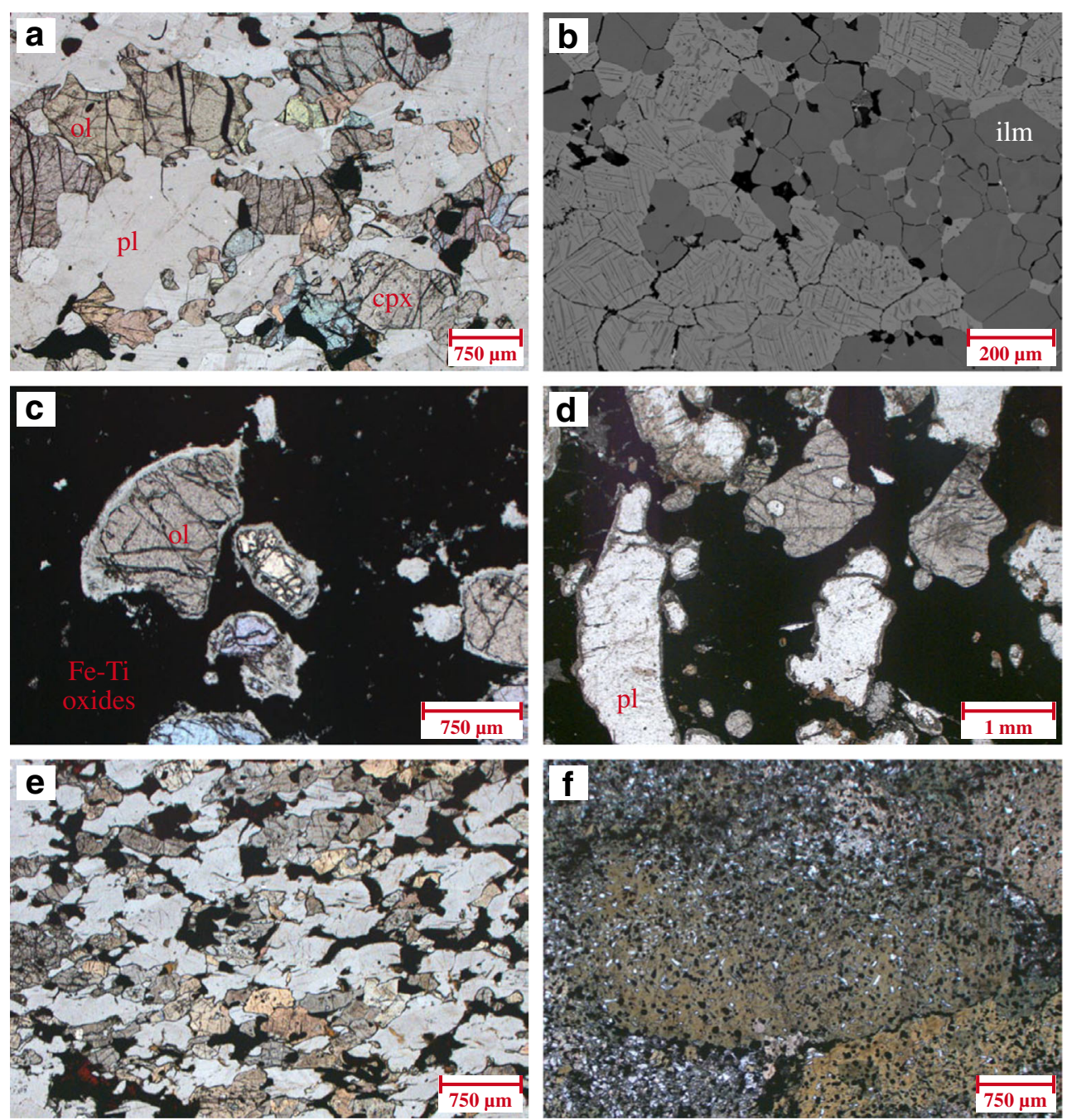

Fig. 3 Photomicrographs of major rock types from the Jameson Range intrusion. a Anhedral olivine with minor clinopyroxene in a leucoolivine-gabbronorite; plane polarised light (PPL), sample TD5-7255. b Back-scatter electron (BSE) image of massive magnetitite consisting of granular ilmenite and titanomagnetite with abundant ilmenite exsolution lamellae, sample TD2-9972. c Olivine inclusions in magnetitite. Note the large grain size of olivine compared to the grain size of Fe-Ti oxides shown in $\mathbf{b}$. The samples are $4 \mathrm{~m}$ apart from each other; PPL, sample

for 10 to $15 \mathrm{vol} \%$ each, whereas orthopyroxene is virtually absent. Intercumulus Fe-Ti oxides constitute 1 to 5 vol\% and consist of homogenous ilmenite and titanomagnetite subgrains, which often exhibit a thin biotite rim.

\section{Fine-grained olivine-gabbronorite}

The fine-grained olivine-gabbronorite is an equigranular cumulate rock type with 40 to 50 vol\% plagioclase, 20 to 30 vol\% ortho- and clinopyroxene, 10 to 20 vol\% olivine and 8 to 12 vol\% Fe-Ti oxides (Fig. 3e). Plagioclase commonly occurs as anhedral grains of 0.4 to $0.8 \mathrm{~mm}$ often containing apatite prisms reaching $0.4 \mathrm{~mm}$ in length. Pyroxene ranges
TD2-9570. d Plagioclase and pyroxene inclusions in magnetitegabbronorite; PPL, sample TMD2-3343. e Typical mineral assemblage of a fine-grained olivine-gabbronorite comprising olivine, clino- and orthopyroxene, plagioclase and interstitial Fe-Ti oxides; PPL, sample TD2-2808. f Amphibole porphyroblast (?, yellow interference colour) enclosing plagioclase and $\mathrm{Fe}-\mathrm{Ti}$ oxides (opaque) in an amphibolephyric dolerite dyke; PPL, sample TD2-19092. Abbreviations: $o l=$ olivine; $c p x=$ clinopyroxene, $p l=$ plagioclase,$i l m=$ ilmenite

from 0.3 to $0.8 \mathrm{~mm}$, whereas anhedral olivine occurs as slightly smaller grains reaching up to $0.6 \mathrm{~mm}$.

\section{Amphibole-phyric dolerite}

The amphibole-phyric dolerite is an exceptionally inequigranular rock dominated by large porphyroblastic brown green amphibole of up to $7 \mathrm{~mm}$ across. The grains generally enclose very fine-grained subhedral prismatic to spherical plagioclase crystals ranging from 10 to $50 \mu \mathrm{m}$ as well as anhedral to subhedral Fe-Ti oxides of comparable size (Fig. 3f). The matrix consists of a similar mineral assemblage but with much smaller amphibole barely reaching $50 \mu \mathrm{m}$. 


\section{Plagioclase-phyric dolerite}

Due to the lack of thin sections of the plagioclase-phyric dolerite, only macroscopic descriptions can be provided. The rock is a very fine-grained dark green dolerite with abundant plagioclase phenocrysts of up to $2 \mathrm{~mm}$. The dolerite clearly crosscuts the layered sequence.

\section{Ore mineralogy}

In general, all lithologies contain a limited amount of sulphides, reaching 1 to 2 vol\% at most. Hence, the mineralised intersections are difficult to identify macroscopically. The sulphide mineral assemblage is not consistent throughout the examined drill holes. In drill holes TMD002 and WMTD5, the sulphides mainly comprise bornite, chalcopyrite and minor pentlandite (Fig. 4a). However, secondary covellite and chalcocite progressively replace bornite and chalcopyrite in samples from shallower depths, such as in drill hole WMTD5 (Fig. 4b, c). They mostly occur as irregular-shaped sulphide aggregates interstitial to Fe-Ti oxides in the magnetitite. Exsolved chalcopyrite lamellae in bornite are also common in these sulphides. In contrast, the mineral assemblage in drill hole WMTD2 consists of pyrrhotite, chalcopyrite and minor pentlandite. The sulphides usually occur along the margins of Fe-Ti oxide grains and to a lesser extent interstitial to silicates
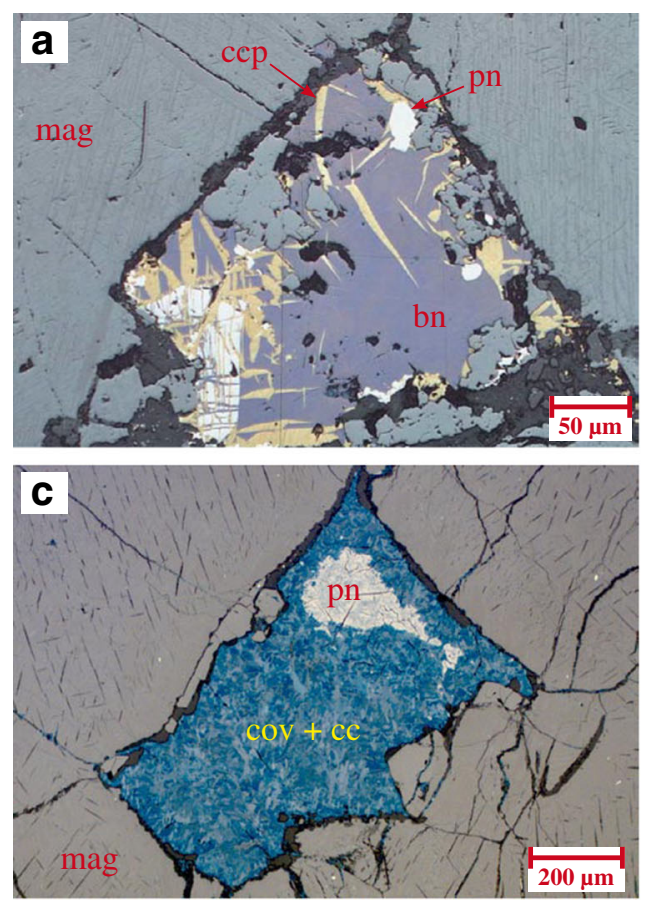

Fig. 4 Photomicrographs of sulphides from the Jameson Range intrusion. a Bornite with acicular chalcopyrite exsolutions and minor pentlandite in magnetitite; reflected light (REF), sample TMD2-3329. b Globular intergrowth of chalcopyrite and supergene covellite in magnetitite; REF, sample TD5-4373. c Intimate intergrowth of covellite and chalcocite with minor pentlandite in magnetitite; REF, sample TD5-
(Fig. 4d). Locally, chalcopyrite may also be spatially associated with alteration halos composed of chlorite and actinolite as well as fractures in silicates and Fe-Ti oxides.

Platinum-group minerals (PGM) in surface samples from the basal magnetite layer were previously studied by Goemann (2012). The author identified 14 grains mainly representing two groups of PGM: (1) a Pt-Fe alloy and (2) a Pd-rich phase with varying proportions of $\mathrm{Pt}, \mathrm{Pb}, \mathrm{Cu}$ and $\mathrm{Sn}$. These minerals are typically associated with fractures in Fe-Ti oxides and altered silicates. Some lath-shaped PGM reach up to $30 \mu \mathrm{m}$ in length, whereas most grains are anhedral and smaller than $5 \mu \mathrm{m}$.

\section{Sampling and analytical methods}

During the late 1990s, WMC Resources drilled 8 diamond and 20 reverse circulation (RC) drill holes within the Jameson Range intrusion targeting titaniferous magnetite layers enriched in V and PGE. For this study, WMC Resources' diamond drill cores WMTD2 and WMTD5 were made available by Anglo American for detailed core-logging and sampling. Additionally, geochemical assays of 3 diamond and $17 \mathrm{RC}$ drill holes were also provided in a historic report (WMC Resources Ltd. 2001).

In 2011, Traka Resources Ltd completed a drill programme comprising ten drill holes within the Jameson Range. As diamond drill core TMD002 was co-funded by the Government
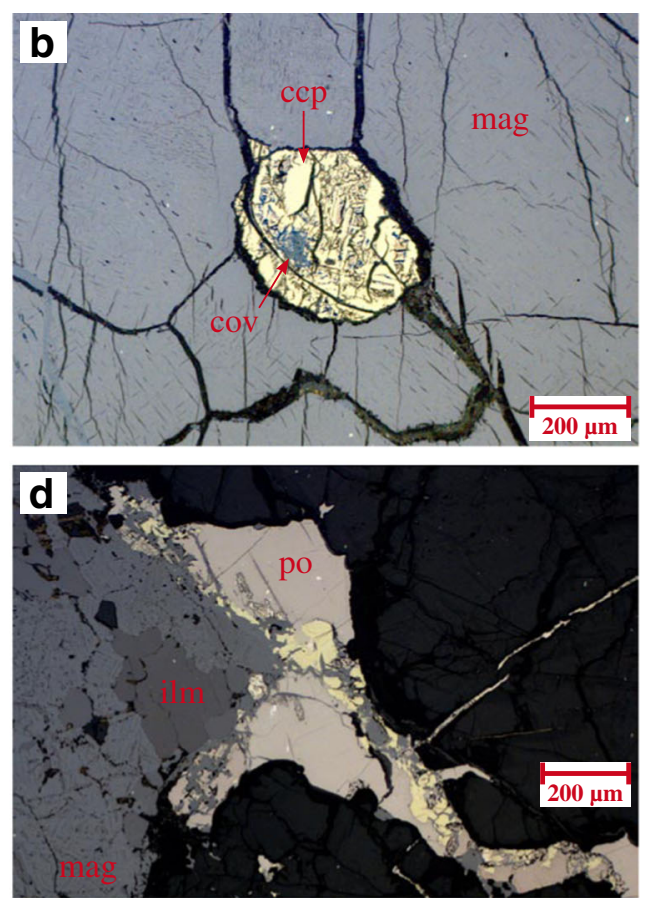

4326. d Interstitial compound sulphide grain consisting of pyrrhotite, chalcopyrite and minor pentlandite attached to the margin of a Fe-Ti oxide grain; REF, sample TD2-10799. Abbreviations: $c c p=$ chalcopyrite, $b n=$ bornite,$p n=$ pentlandite, $c o v=$ covellite, $c c=$ chalcocite, $p o=$ pyrrhotite, $m a g=$ magnetite, $\mathrm{ilm}=$ ilmenite 
of Western Australia's "Exploration Incentive Scheme”, it was available for this study at the GSWA's core library in Perth for sampling. The location of the sampled drill holes is shown in Fig. 2.

Following careful logging of drill cores WMTD2 and WMTD5, a set of 22 samples was collected representing the different recognised rock types. Furthermore, a total of 25 samples were collected from drill core TMD002. The samples were doubly numbered, photographed and packed for shipping.

Forty-seven samples were submitted to ACME Analytical Laboratories in Vancouver (now: Bureau Veritas Mineral Laboratories) for whole rock and trace element geochemical analysis. A combination of fire assay, aqua regia digestion, fusion digestion with subsequent dilute nitric acid digestion and multi-acid digestion followed by inductively coupled plasma-emission spectroscopy (ICP-ES) or inductively coupled plasma-mass spectrometry (ICP-MS) was used to determine major and trace element concentrations. Sulphur was analysed using the Leco furnace method. Moreover, two PGErich samples from the basal magnetite layer were sent to Intertek Genalysis Perth for nickel sulphide fire assay with subsequent ICP-MS analysis in order to determine the concentrations of $\mathrm{Pt}, \mathrm{Pd}, \mathrm{Rh}, \mathrm{Os}, \mathrm{Ir}$ and $\mathrm{Ru}$. Two standards were used to monitor the quality of the analyses (AMIS0013, AMIS0278; African Mineral Standards).

Automated SEM analysis was carried out on a FEI Quanta 650 MLA-FEG equipped with two Bruker Quantax X-Flash 5010 EDS detectors at the Department of Mineralogy, TU Bergakademie Freiberg. A mineral map of the base of a PGE-rich magnetitite sample was produced in a grain-based energy dispersive X-ray spectroscopy mapping mode (GXMAP). Moreover, the modal mineralogy of four magnetitite samples was determined using an automated point counting method (XMOD) (Fandrich et al. 2007).

Mineral compositions were determined by electron microprobe analysis at the Helmholtz Institute Freiberg for Resource Technology using a JEOL JXA-8530F fitted with a field emission gun and five wavelength-dispersive spectrometers. Analyses were carried out with autofocus using an accelerating voltage of $20 \mathrm{kV}, 12 \mathrm{nA}$ beam current and a spot size of 2-4 $\mu \mathrm{m}$. The counting time was 10 to $40 \mathrm{~s}$ for major elements and 40 to $60 \mathrm{~s}$ for trace elements, respectively. Further details regarding used X-ray lines, positions and measurement times on peak and background and the lower limit of detection can be found in the electronic appendix. Natural minerals and synthetic metals from ASTIMEX Ltd. were used for calibration. Magnetite, diopside and olivine from the same supplier were measured during the analytical runs to monitor instrumental drift. Mutual interferences were corrected for $\mathrm{Zn} \mathrm{L} \beta_{1}$ on $\mathrm{Na} \mathrm{K} \alpha_{1,2}, \mathrm{~V} \mathrm{~K} \beta_{1,3}$ on $\mathrm{Cr} \mathrm{K} \alpha_{1}$ and $\mathrm{Ti} \mathrm{K} \beta_{1,3}$ on $\mathrm{V} \mathrm{K} \alpha_{1}$ using the offline overlap correction method of Osbahr et al. (2015). Correction factors were determined with $0.0656,0.0939$ and 0.0449 , respectively. Iron was measured as FeO. The trivalent iron in spinel group phases was calculated assuming stoichiometry. Analyses with totals below 98 and above 102 wt\% were eliminated from the dataset as well as obvious mixed analyses between two phases.

\section{Lithostratigraphic relationships in the Jameson Range}

The stratigraphy of the Jameson Range intrusion remains largely unresolved mainly because of poor exposure and limited drilling in the area. Although data from historic drilling cover a fairly large area of the intrusion, the drill holes are generally short making a precise correlation challenging. Most of the drill holes range from 60 to $120 \mathrm{~m}$ in depth and only two exceed $200 \mathrm{~m}$ (ESM 2: Table S1).

Nevertheless, drill data coupled with total magnetic intensity maps and field observations allow for a meaningful inference of the Jameson Range stratigraphy contributing to a better understanding of the layered sequence. Figure 5 shows a generalised stratigraphic section through the intrusion based on historic drilling data from WMC Resources Ltd (2001) assuming a dip of $30^{\circ}$. The profile highlights magnetitites and P-rich lithologies defined by $>50$ wt $\% \quad \mathrm{Fe}_{2} \mathrm{O}_{3}(\mathrm{t})$ and $>0.6$ wt $\% \quad \mathrm{P}_{2} \mathrm{O}_{5}$, respectively. The base of the Upper Zone of the Jameson Range, corresponding with Daniels' (1974) Zone 4, is defined by the occurrence of the first (basal) massive magnetite layer, which has been intersected by three diamond drill holes and one RC drill hole. Drilling indicates that the basal magnetite layer reaches a thickness of up to $3 \mathrm{~m}$, whereas Maier et al. (2014) reported a thickness of up to $50 \mathrm{~m}$, possibly due to duplication. The main rock types in the Upper Zone are plagioclase-rich layered adcumulates ranging from gabbronorite and troctolite to anorthosite with substantial amounts of Fe-Ti oxides. Little information is available on the layered sequence from approx. 300 to $1100 \mathrm{~m}$ above the basal magnetite layer (abML), but a P-rich layer of up to $12 \mathrm{~m}$ occurs $1100 \mathrm{~m}$ abML followed by another magnetite layer of $2 \mathrm{~m}$ thickness only $30 \mathrm{~m}$ above this. A 59-m-thick zone, characterised by an enrichment in $\mathrm{P}$, appears approx. $1250 \mathrm{~m}$ abML. The interval between 1250 and $2000 \mathrm{~m}$ abML has not been intersected by any drill holes, but two magnetite layers at approx. $2100 \mathrm{~m}$ abML are reasonably well-defined. They reach a thickness of 2 and $6 \mathrm{~m}$, respectively, followed by P-rich zone of up to $12 \mathrm{~m}$. The stratigraphically uppermost drill holes reveal the presence of an additional set of four magnetitites between 2600 and $2750 \mathrm{~m}$ abML ranging from 1 to $10 \mathrm{~m}$ in thickness. Two P-rich zones of 1 and 


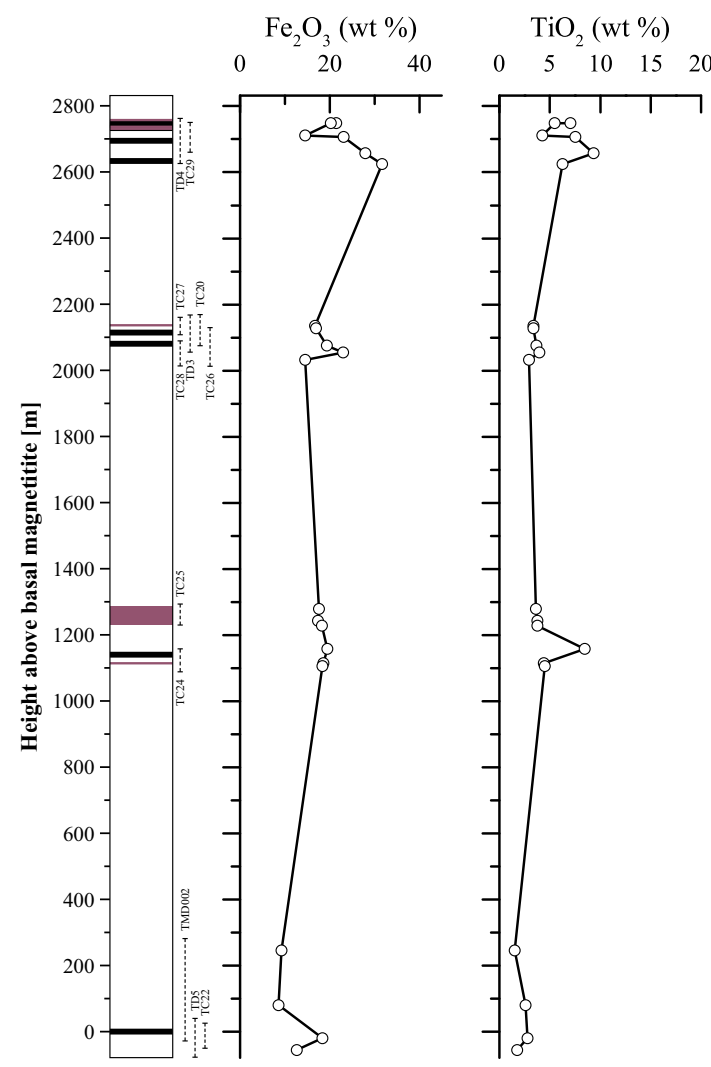

Fig. 5 Simplified stratigraphic column through the upper part of the Jameson Range intrusion starting at the basal magnetite layer assuming a dip of $30^{\circ}$. Drill holes intersecting the layered succession are shown

$18 \mathrm{~m}$ thickness, respectively, are also present, one of which is spatially related to the second magnetite layer from the top. This is the only P-rich interval within a magnetite layer, whereas all others are spatially separated from the magnetitites. Generally, the $\mathrm{P}$ enrichment occurs at the top of each intersected set of magnetite layers. Even though the lowermost P-rich zone appears below a magnetite layer, more layers may be present at depth.

In order to illustrate the variability of individual layers, ESM 3: Fig. S2 shows a stratigraphic correlation between five drill holes presumably intersecting the same magnetite- and P-enriched horizon at approx. $2100 \mathrm{~m}$ abML. Notably, the distribution of magnetiterich lithologies defined by $>30$ wt $\% \mathrm{Fe}_{2} \mathrm{O}_{3}(\mathrm{t})$ (magnetitites, magnetite-gabbroid) is complex, with magnetite forming both massive layers as well as thick zones of magnetite-gabbroids. Magnetitites and magnetite-gabbroids are somewhat interchangeable; however, the upper part of the magnetite-rich zone is mostly well-defined by the occurrence of a magnetitite. The intersected P-rich layer is mostly present in close proximity to the upper magnetitite. In drill hole WMTC20, P enrichment occurs in two separate zones, whereas drill holes WMTD3 and WMTC27 have a single P-enriched layer of variable thickness.

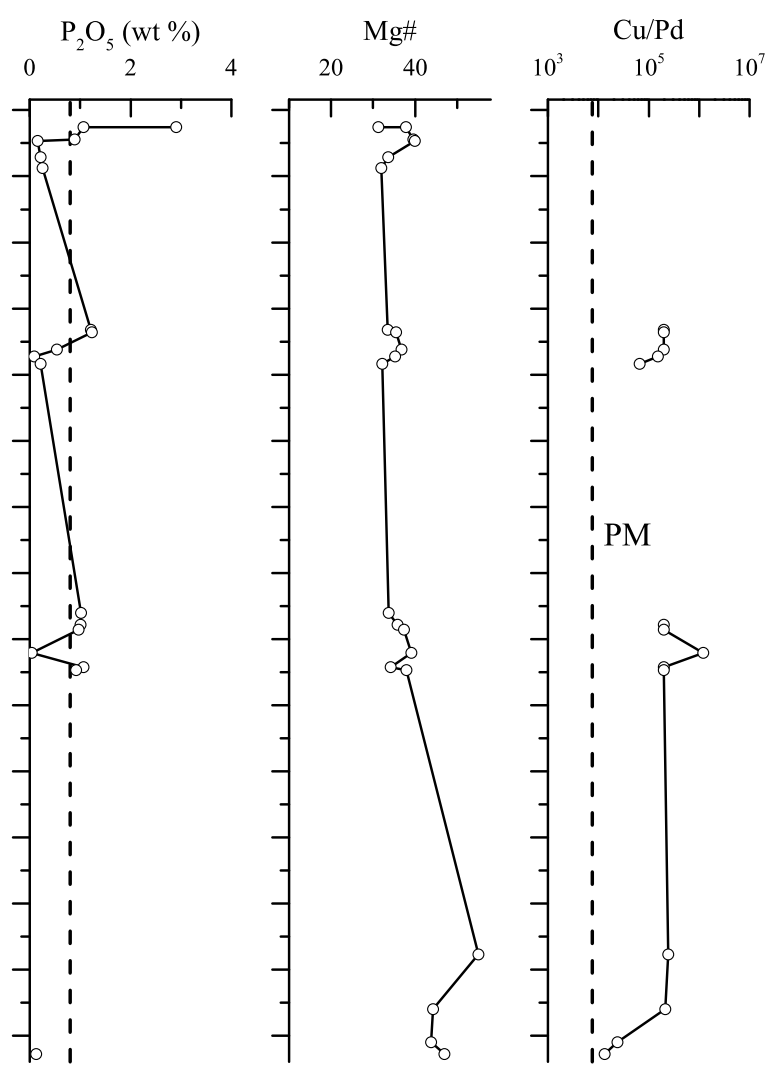

next to the log. Magnetitites are represented as black layers and P-rich lithologies as pink layers. $\mathrm{Bulk} \mathrm{Fe}_{2} \mathrm{O}_{3}, \mathrm{TiO}_{2}$ and $\mathrm{P}_{2} \mathrm{O}_{5}$ concentrations as well as $\mathrm{Mg} \#$ and the $\mathrm{Cu} / \mathrm{Pd}$ ratio are also displayed

\section{Analytical results}

\section{Mineral chemistry}

The mineral chemistry of rock-forming minerals from the Jameson Range was investigated in a set of six samples. The full dataset of mineral compositions can be found in the electronic appendix. Olivine is present in all analysed samples. The leuco-olivine-gabbronorite and the magnetitite contain olivine with forsterite (Fo) contents ranging from $\mathrm{Fo}_{51}$ to $\mathrm{Fo}_{60}$, whereas olivine from the leuco-olivine-gabbro has slightly lower Fo contents varying between $\mathrm{Fo}_{44}$ and $\mathrm{Fo}_{51}$ (Fig. 6a). In contrast, the fine-grained olivine-gabbronorite is characterised by extremely low Fo contents with $\mathrm{Fo}_{24}$ to $\mathrm{Fo}_{28}$. The $\mathrm{Ni}$ concentrations in olivine vary from 340 to $1029 \mathrm{ppm}$ in the leucocratic rock types and the magnetitite. However, one sample from drill hole WMTD5 has slightly higher Ni concentrations of up to $1210 \mathrm{ppm}$. Olivine from the fine-grained olivinegabbronorite has the lowest $\mathrm{Ni}$ concentrations with less than $500 \mathrm{ppm}$. Hence, a broadly positive correlation between Fo and Ni is evident. Average plagioclase compositions in the leucocratic rock types show a very limited range in anorthite $(\mathrm{An})$ content varying from $\mathrm{An}_{56}$ 


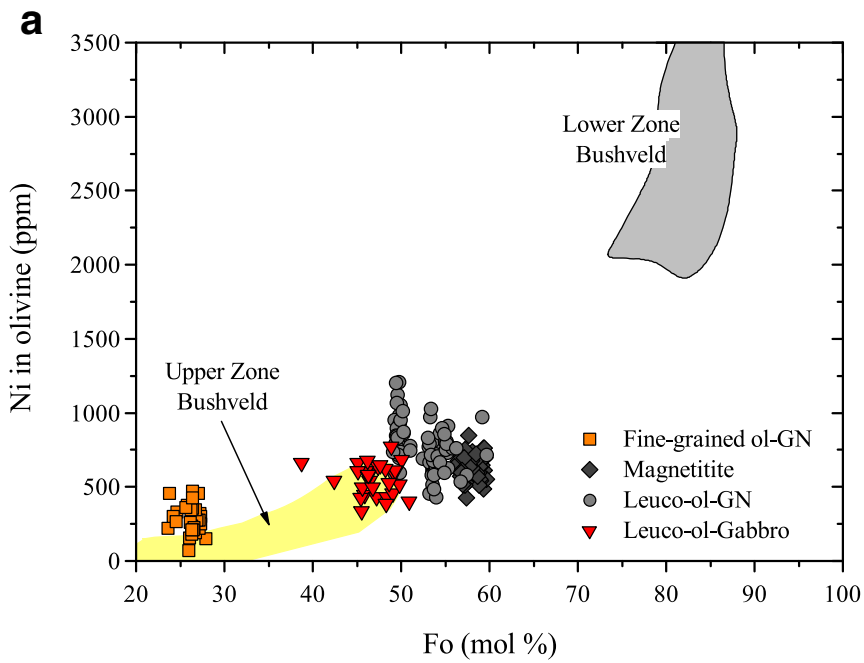

Fig. 6 Mineral chemistry of different rock-forming minerals in the Jameson Range lithologies. a Plot of $\mathrm{Ni}$ in olivine vs. its forsterite (Fo) content. b $\mathrm{Mg \#}$ in orthopyroxene (opx) vs. anorthite $(A n)$ content. Bushveld Lower Zone data are taken from Teigler and Eales (1996).

to $\mathrm{An}_{59}$ (Fig. 6b). The fine-grained olivine-gabbronorite has an even lower An content of $\mathrm{An}_{54}$. Orthopyroxene is also relatively limited in its compositional range. In the leucocratic rock types, the $\mathrm{Mg} \#(100 \times \mathrm{Mg} /(\mathrm{Mg}+\mathrm{Fe}))$ of orthopyroxene varies between 60 and $61 \mathrm{~mol} \%$, whereas orthopyroxene from the fine-grained olivine-gabbronorite has a lower average $\mathrm{Mg \#}$ of $52 \mathrm{~mol} \%$. The variation in clinopyroxene composition is slightly greater with $\mathrm{Mg} \#$ ranging from 70 to $75 \mathrm{~mol} \%$ in the leucocratic rock types and the magnetitite. The fine-grained olivine-gabbronorite contains clinopyroxene with Mg\#=65 mol \%. Magnetite from the Jameson Range intrusion has relatively low $\mathrm{TiO}_{2}$ concentrations ranging from 0.39 to $3.04 \mathrm{wt} \%$, thus representing near end-member magnetite (Fig. 7a, c). Trace element abundances show distinct compositional differences between magnetite from drill holes WMTD2 and WMTD5. Magnetite from the latter has much higher $\mathrm{Cr}(10,037 \pm 1189 \mathrm{ppm} \mathrm{Cr}, n=5)$ and $\mathrm{V}$ concentrations $(11,593 \pm 1090 \mathrm{ppm} \mathrm{V}, n=5)$ than the ones from drill hole WMTD2 with $624 \pm 305 \mathrm{ppm} \mathrm{Cr}$ and $8801 \pm 848 \mathrm{ppm} \mathrm{V}$ $(n=10)$ (Fig. 7b). Average $\mathrm{Al}$ concentrations are slightly higher in magnetite from WMTD2 with $3659 \pm 2041 \mathrm{ppm}$ Al compared to $2373 \pm 168 \mathrm{ppm} \mathrm{Al}$ in magnetite from WMTD5. Magnesium concentrations in magnetite are largely similar among the two drill holes with $357 \pm 74 \mathrm{ppm} \mathrm{Mg}$ in WMTD5 and 426 $\pm 247 \mathrm{ppm} \mathrm{Mg}$ in WMTD2, respectively (Fig. 7d).

\section{Whole rock geochemistry}

A total of 47 samples representing all rock types recognised from three drill holes intersecting the Jameson Range were analysed for whole rock geochemistry. The full data set of

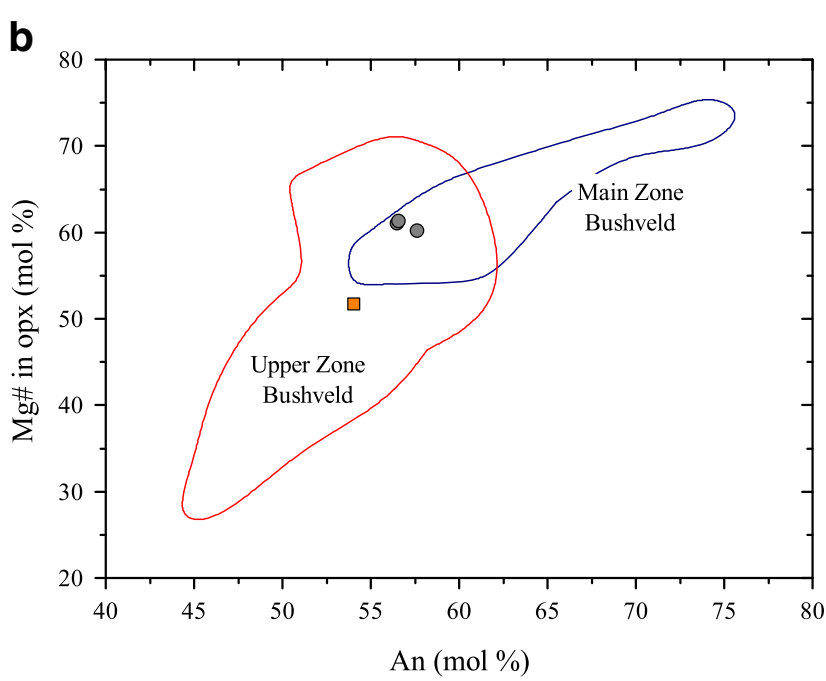

Upper Zone olivine chemistry is from Barnes (unpublished data). Main and Upper Zone data in b are taken from Roelofse and Ashwal (2012). Abbreviations: $G N=$ gabbronorite, $o l=$ olivine

whole rock geochemical analyses can be found in the electronic appendix.

\section{Major element geochemistry}

The major oxide variation in the Jameson Range mainly reflects the proportion of each cumulus mineral. Most of the rock types consist of variable proportions of olivine, pyroxene, plagioclase and magnetite. In a plot of $\mathrm{Fe}_{2} \mathrm{O}_{3}$ $+\mathrm{TiO}_{2}+\mathrm{V}$ vs. $\mathrm{Al}_{2} \mathrm{O}_{3}$, the magnetite component can be effectively separated from plagioclase as well as olivine and pyroxene (Fig. 8a). The leucocratic rock types show varying amounts of plagioclase and magnetite with minor amounts of ferromagnesian silicates. The finegrained olivine-gabbronorite and the amphibole-phyric dolerite plot in close proximity to the leucocratic rock types but with less plagioclase. The magnetitegabbronorite samples plot close to the plagioclasemagnetite tie-line indicating that these minerals are the main components. Generally, plagioclase appears to be the main constituent of the silicate lithologies (Fig. 8b, c). The magnetitites, however, can be subdivided into two groups: (1) magnetitites on the plagioclasemagnetite tie-line and (2) magnetitites on the ferromagnesian silicate-magnetite tie-line, reflecting the different silicate components in the magnetitites. The second group of magnetitites seems to be dominated by olivine as the ferromagnesian silicate, even though varying proportions of plagioclase, ortho- and clinopyroxene may also be present (Fig. 8c). All of the intersected rock types, except for the amphibolephyric dolerite, represent meso- to adcumulates with relatively little trapped liquid as indicated by the low $\mathrm{Zr}$ 
a
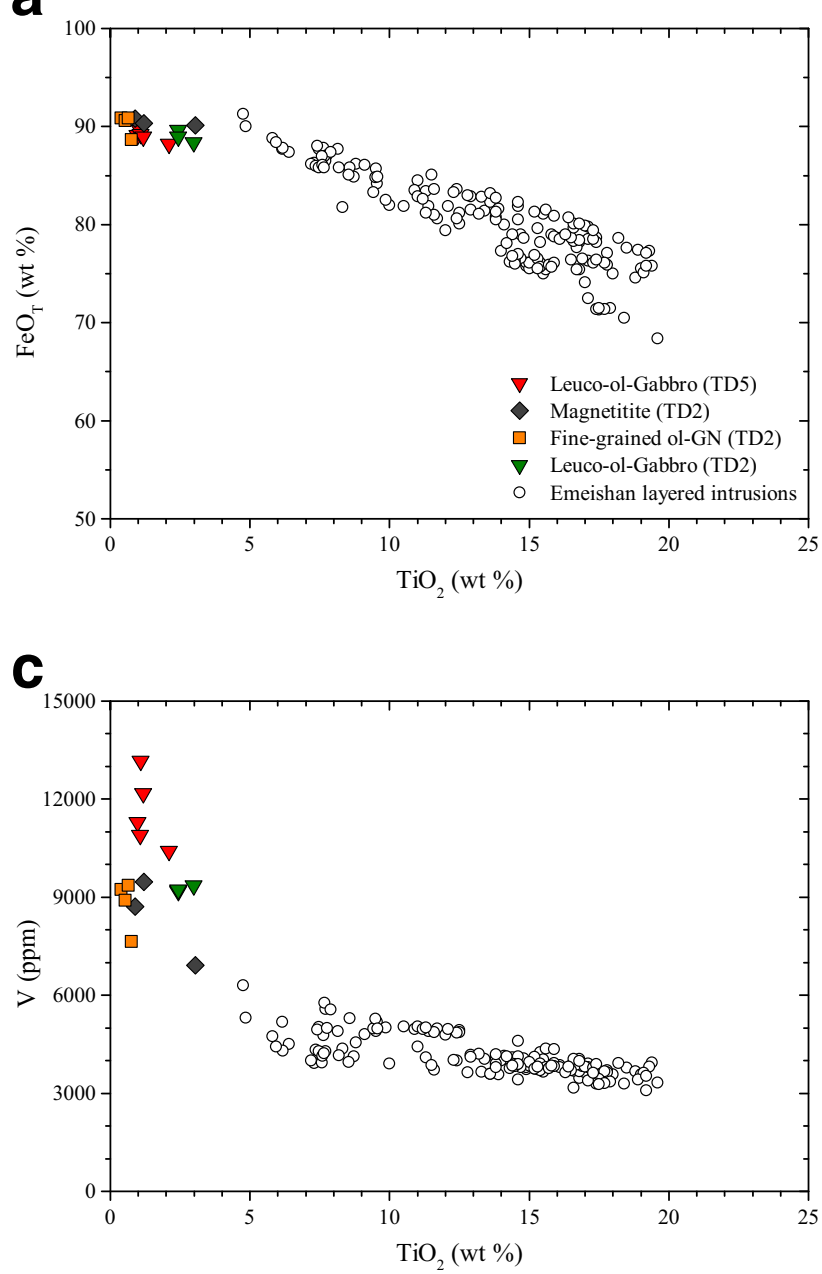

b

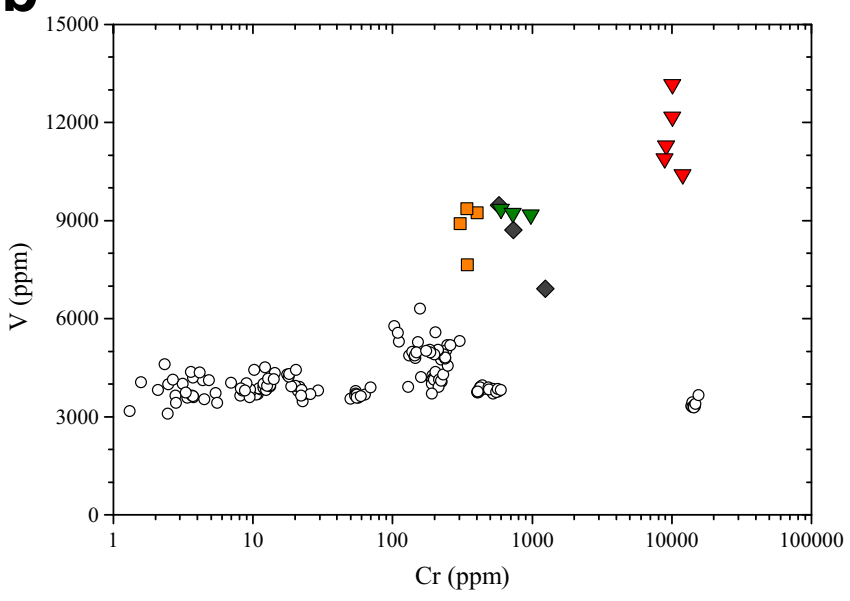

d

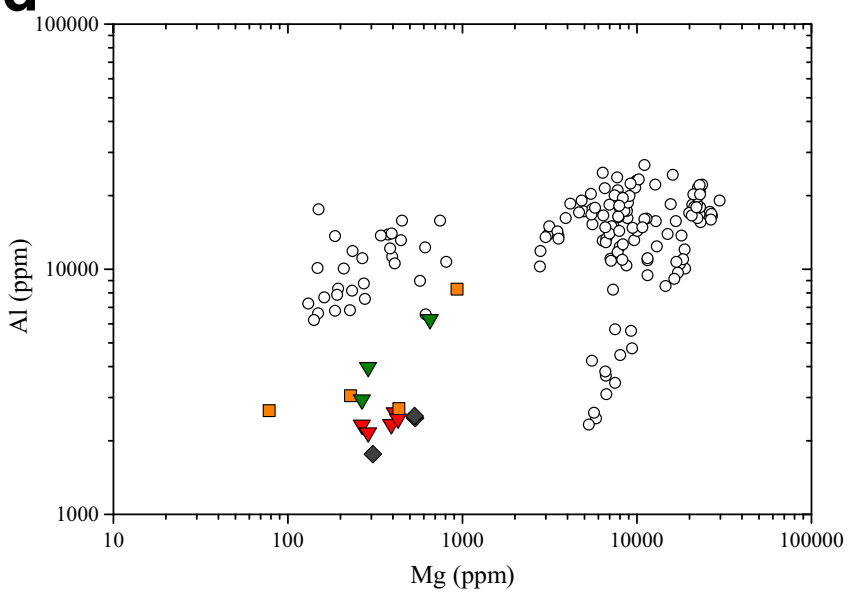

Fig. 7 Composition of magnetite from the Jameson Range. a $\mathrm{TiO}_{2}$ vs. $\mathrm{FeO}_{\mathrm{T}}$. b V vs. Cr. c V vs. $\mathrm{TiO}_{2}$. d Al vs. Mg. Data for the Emeishan layered intrusions are taken from Liu et al. (2015)

concentrations in these rocks ranging from 14 to $95 \mathrm{ppm}$ (Fig. 8d). Only the amphibole-phyric dolerite has significantly higher $\mathrm{Zr}$ concentrations with $271 \mathrm{ppm}$. Notably, there is a relatively well-defined negative correlation between $\mathrm{MgO}$ and $\mathrm{Zr}$ among the magnetitites indicating that the purest magnetitites are the ones with the highest $\mathrm{Zr}$ concentrations. Magnetitites from the Upper Zone of the Bushveld Complex described by Barnes et al. (2004) appear to plot close to the first group of magnetitites on the plagioclase-magnetite tie-line, whereas magnetitites containing ferromagnesian silicates do not occur in the Bushveld Complex.

\section{Trace element geochemistry}

The leuco-olivine-gabbronorites are characterised by enrichment in rare earth elements (REE) covering a range from 9 to 32 times chondrites. The average sample shows fractionated light rare earth elements (LREE) with $\mathrm{La} / \mathrm{Sm}_{\mathrm{N}}=2.79$ and $\mathrm{mi}$ nor fractionation of the heavy rare earth elements (HREE) with $\mathrm{Tb} / \mathrm{Yb}_{\mathrm{N}}=1.34$ (Fig. 9a). Moreover, these rocks have a distinctly positive $\mathrm{Eu}$ anomaly with $\mathrm{Eu} / \mathrm{Eu}^{*}=3.64[\mathrm{Eu} /$ $\left.\mathrm{Eu}^{*}=2 \mathrm{Eu}_{\mathrm{N}} /\left(\mathrm{Sm}_{\mathrm{N}}+\mathrm{Gd}_{\mathrm{N}}\right)\right]$. The leuco-olivine-gabbro intersected in drill hole WMTD2 shares many similarities with the previous rock type. The samples cover a range from 18 to 22 times chondrites with less fractionated LREE (La/ $\left.\mathrm{Sm}_{\mathrm{N}}=2.04\right)$ but stronger fractionation of HREE $(\mathrm{Tb} /$ $\left.\mathrm{Yb}_{\mathrm{N}}=1.94\right)$ and a less pronounced $\mathrm{Eu}$ anomaly $(\mathrm{Eu} /$ $\mathrm{Eu}^{*}=1.72$ ). The magnetite-gabbronorites cover a lower range in REE enrichment with 4 to 12 times chondrites. The fractionation of LREE is similar to that from the leuco-olivinegabbronorites with $\mathrm{La} / \mathrm{Sm}_{\mathrm{N}}=2.83$, whereas the HREE are somewhat erratic, possibly due to low concentrations of these elements explaining the low $\mathrm{Tb} / \mathrm{Yb}_{\mathrm{N}}$ ratio of 0.90 (Fig. 9b). The magnetitites show even lower REE enrichments with 1.3 to 6 times chondrites, which is reflected in highly inconsistent REE patterns. On average, the magnetitites have fractionated LREE and to a lesser extent HREE with $\mathrm{La} / \mathrm{Sm}_{\mathrm{N}}=2.71$ and $\mathrm{Tb} / \mathrm{Yb}_{\mathrm{N}}=1.19$, respectively (Fig. 9c). Some samples also exhibit a slightly positive $\mathrm{Eu}$ anomaly with $\mathrm{Eu} / \mathrm{Eu}^{*}=1.39$. In 

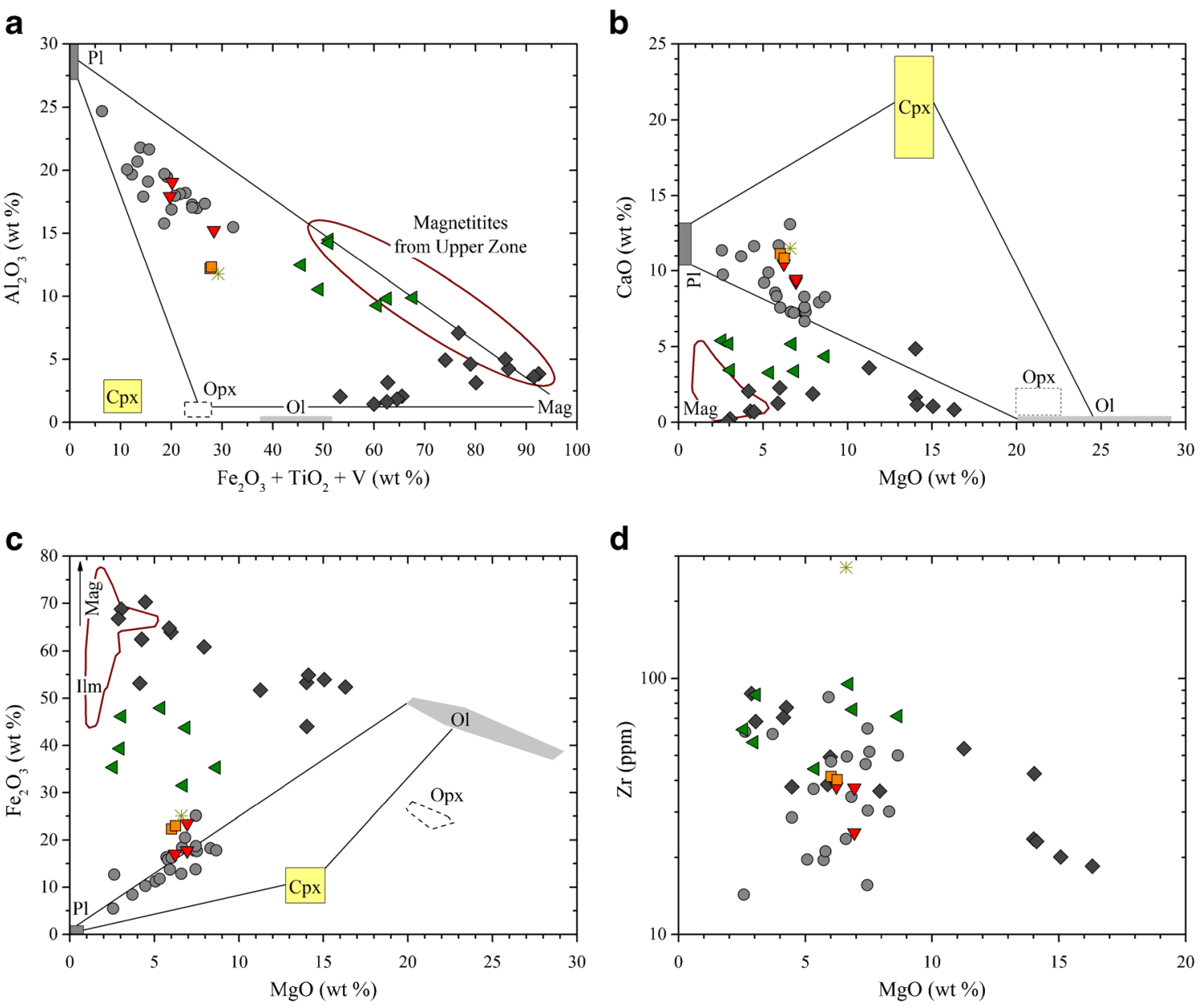

d
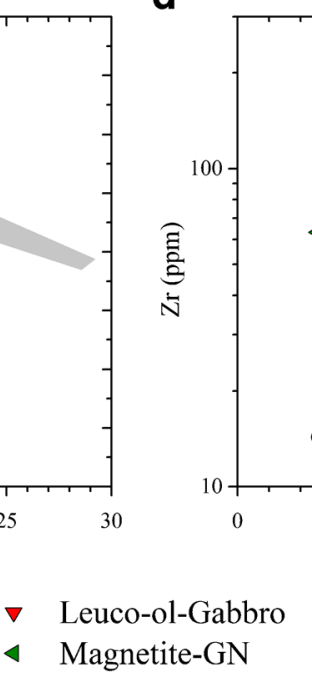

magnetitites. Bushveld Upper Zone magnetitite data (dark red field) are taken from Barnes et al. (2004). Abbreviations: $G N=$ gabbronorite, $o l=$ olivine,$o p x=$ orthopyroxene, $c p x=$ clinopyroxene, $p l=$ plagioclase, $m a g=$ magnetite,$i l m=$ ilmenite, amph $=$ amphibole

contrast, the clinopyroxene-rich magnetitite has comparably higher absolute REE abundances of up to ten times chondrites. The samples have low $\mathrm{La} / \mathrm{Sm}_{\mathrm{N}}$ ratios of 0.63 and relatively fractionated HREE $\left(\mathrm{Tb} / \mathrm{Yb}_{\mathrm{N}}=2.00\right)$. Moreover, they are characterised by a distinctly negative Eu anomaly with $\mathrm{Eu} /$ $\mathrm{Eu}^{*}=0.70$. The fine-grained olivine-gabbronorite shows significantly higher REE enrichment reaching up to 38 times chondrites (Fig. 9d). As opposed to the previous lithologies, these samples have unfractionated LREE with $\mathrm{La} / \mathrm{Sm}_{\mathrm{N}}=0.97$ and fractionated HREE with $\mathrm{Tb} / \mathrm{Yb}_{\mathrm{N}}=2.18$. The average $\mathrm{Eu} /$ Eu* ratio of 1.11 corresponds to a minor positive Eu anomaly. The highest enrichment in REE of 118 times chondrites is found in the amphibole-phyric dolerite. The LREE show a moderate degree of fractionation with $\mathrm{La} / \mathrm{Sm}_{\mathrm{N}}=1.49$, whereas the HREE are more fractionated with $\mathrm{Tb} / \mathrm{Yb}_{\mathrm{N}}=1.98$. Similar to the clinopyroxene-rich magnetitites, this rock type is characterised by a negative Eu anomaly with $\mathrm{Eu} / \mathrm{Eu}^{*}=0.75$.
Major minerals concentrating REE, such as allanite, monazite, epidote and sphene, were not observed in these rocks; thus, the REE concentrations of the lithologies are mainly controlled by the cumulus minerals as well as the postcumulus trapped liquid. The REE pattern of the leucocratic units with its distinct positive Eu anomaly clearly reflects the high proportion of plagioclase in these rocks. Magnetitites and magnetite-gabbronorites have generally low total REE abundances due to low REE concentrations in olivine, pyroxene, magnetite and ilmenite. On the other hand, the bell-shaped REE pattern in some magnetitites indicates the presence of cumulus clinopyroxene in these samples. Hence, the trapped liquid component is very limited in all of these samples mainly reflecting REE concentrations in the cumulus minerals. In contrast, the fine-grained olivine-gabbronorite and the amphibole-phyric dolerite contain higher proportions of trapped liquid. 

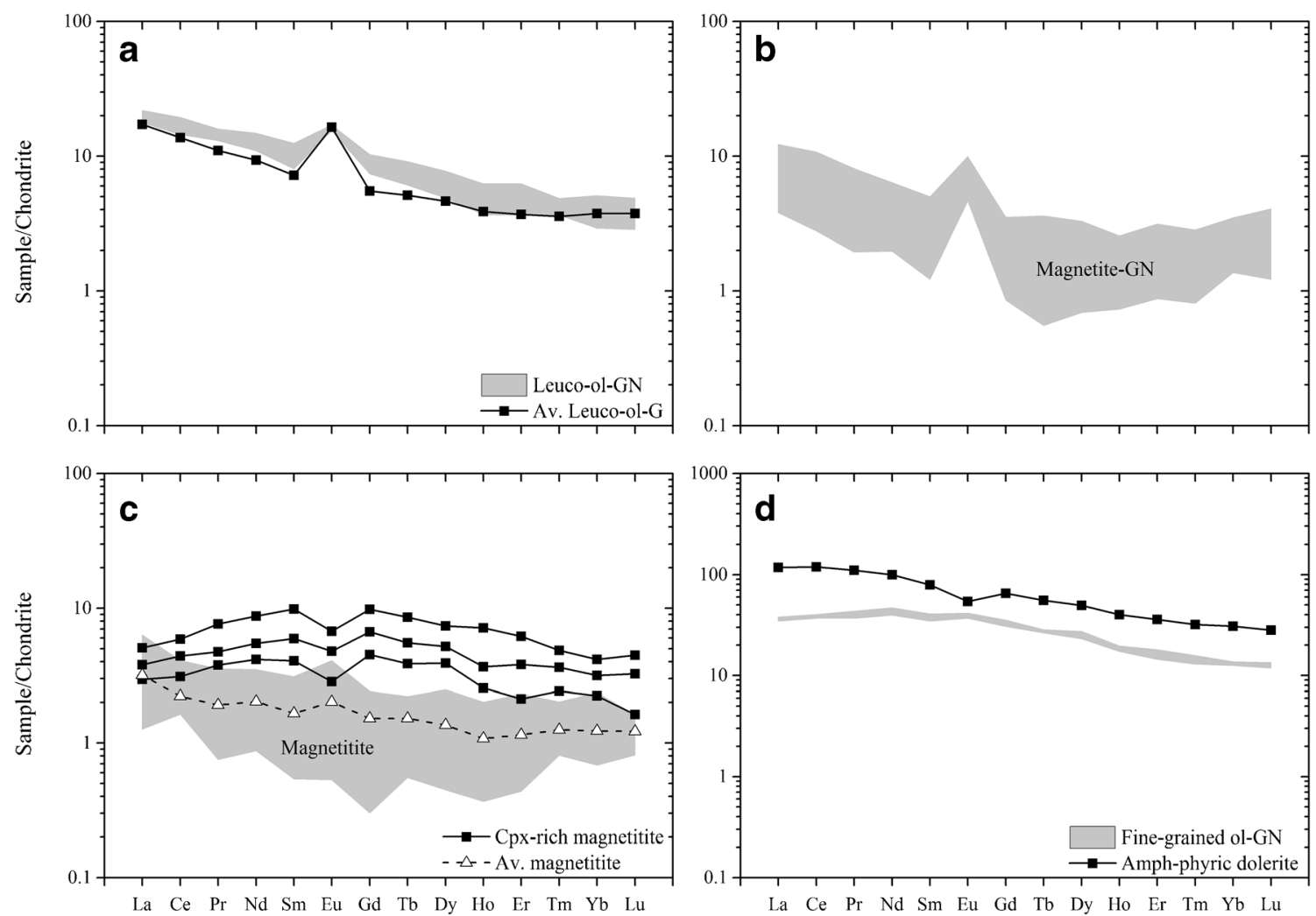

Fig. 9 a-d Chondrite-normalised rare earth element pattern for different rock types from the Jameson Range. Note the change in scale in $\mathbf{d}$. Normalisation values were taken from McDonough and Sun (1995).

Abbreviations: $G N=$ gabbronorite, $G=$ gabbro, $o l=$ olivine, $c p x=$ clinopyroxene, amph = amphibole

\section{Chalcophile bulk element chemistry}

Key characteristics of different mineralisation styles associated with mafic-ultramafic magmatism are directly reflected in their chalcophile element distribution. Stratiform PGE reefs, like the Merensky Reef in the Bushveld Complex, are generally characterised by relatively low $\mathrm{S}$ and $\mathrm{Cu}$ concentrations compared to PGE, whereas magmatic sulphide mineralisation shows generally much higher $\mathrm{Cu} / \mathrm{PGE}$ ratios at high $\mathrm{S}$ concentrations (Barnes et al. 1993). The intersected succession below the PGE-rich magnetitite from drill holes WMTD5 and TMD002 is characterised by very low $\mathrm{Cu}, \mathrm{Ni}, \mathrm{Au}$ and $\mathrm{S}$ concentrations, whereas $\mathrm{Pt}$ and $\mathrm{Pd}$ are somewhat higher (Fig. 10a, b). The appearance of the ca. 3-m-thick magnetitite coincides with a sharp increase in chalcophile element concentrations. $\mathrm{Cu}$ increases from less than 100 to $4182 \mathrm{ppm}$ in TMD002 and 3400 ppm in WMTD5. Pt and Pd concentrations also increase dramatically in WMTD5 reaching up to 1386 and $537 \mathrm{ppb}$, respectively. Au is concentrated in the magnetitite with up to $254 \mathrm{ppb}$. Chalcophile element concentrations decrease considerably above the magnetitite, with the exception of $\mathrm{Au}$ that seems to decline more gradually in concentrations compared to $\mathrm{Cu}, \mathrm{Pt}, \mathrm{Pd}$ and $\mathrm{S}$. The rocks overlying the magnetitite are significantly enriched in $\mathrm{Cu}$ and $\mathrm{S}$ compared to those below the magnetitite. Variations in $\mathrm{Cu} / \mathrm{Pd}$

ratios have been routinely used in vectoring towards PGE reefs within layered intrusions (e.g. Maier et al. 2005). The $\mathrm{Cu} / \mathrm{Pd}$ ratios in the Jameson Range intrusion show a clear shift from low $\mathrm{Cu} / \mathrm{Pd}$ ratios, close to the primitive mantle value from Barnes and Maier (1999), below the magnetitite to high $\mathrm{Cu} / \mathrm{Pd}$ ratios above the magnetitite. Notably, there is a sharp decrease in $\mathrm{Cu} / \mathrm{Pd}$ within the mineralised intersection.

Drill hole WMTD2 exhibits low $\mathrm{Cu}$ concentrations throughout most of the intersected lithologies except for the 18-m-thick magnetitite in the central part of the core (Fig. 10c). The upper part of the magnetitite reaches up to 2700 ppm $\mathrm{Cu}$, whereas $\mathrm{Pt}, \mathrm{Pd}$ and $\mathrm{Au}$ show only minor enrichment with less than $70 \mathrm{ppb} \mathrm{Pt}+\mathrm{Pd}+\mathrm{Au}$ at most. $\mathrm{Ni}$ concentrations of up to $1000 \mathrm{ppm}$ are generally restricted to magnetitites, partly due to increased modal abundances of olivine. The peak in chalcophile element concentrations correlates well with an increase in $\mathrm{S}$ concentrations reaching up to $4164 \mathrm{ppm}$. As a result of high $\mathrm{Cu}$ and low $\mathrm{Pd}$ concentrations in the magnetitite, the $\mathrm{Cu} / \mathrm{Pd}$ ratios are above the primitive mantle value with no distinct downhole trend.

The Jameson Range lithologies generally exhibit a relatively well-defined correlation between $\mathrm{Cu}$ and $\mathrm{S}$ contents (Fig. 11a). However, samples from drill hole WMTD2 have markedly lower $\mathrm{Cu} / \mathrm{S}$ ratios compared to samples from drill holes WMTD5 and TMD002, which contain the PGE- 

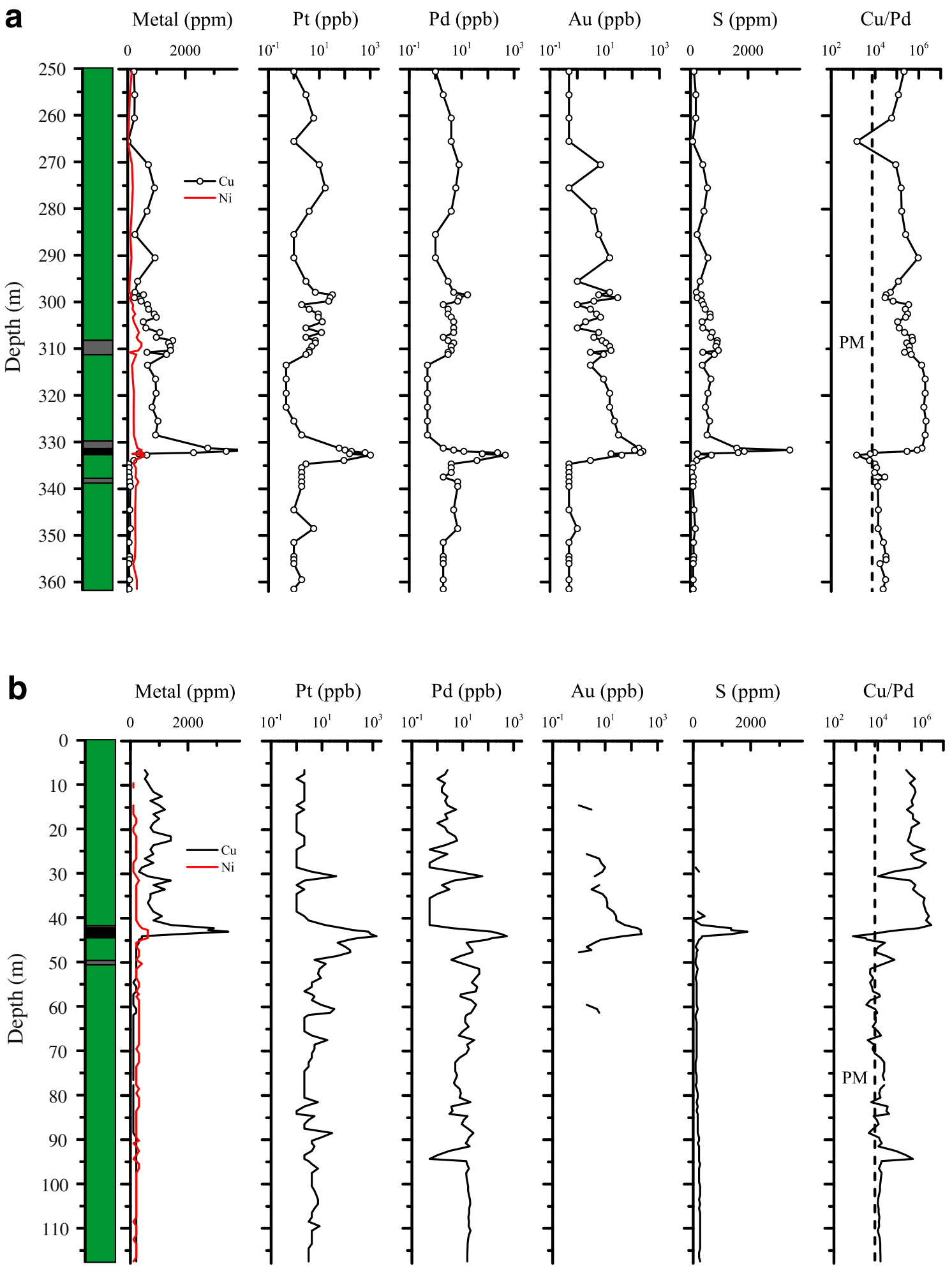

Fig. 10 Downhole chalcophile element bulk chemistry of diamond drill cores intersecting the Jameson Range. a TMD002. b WMTD5. c WMTD2. Primitive mantle (PM) Cu/Pd ratio is taken from Barnes and Maier (1999) 


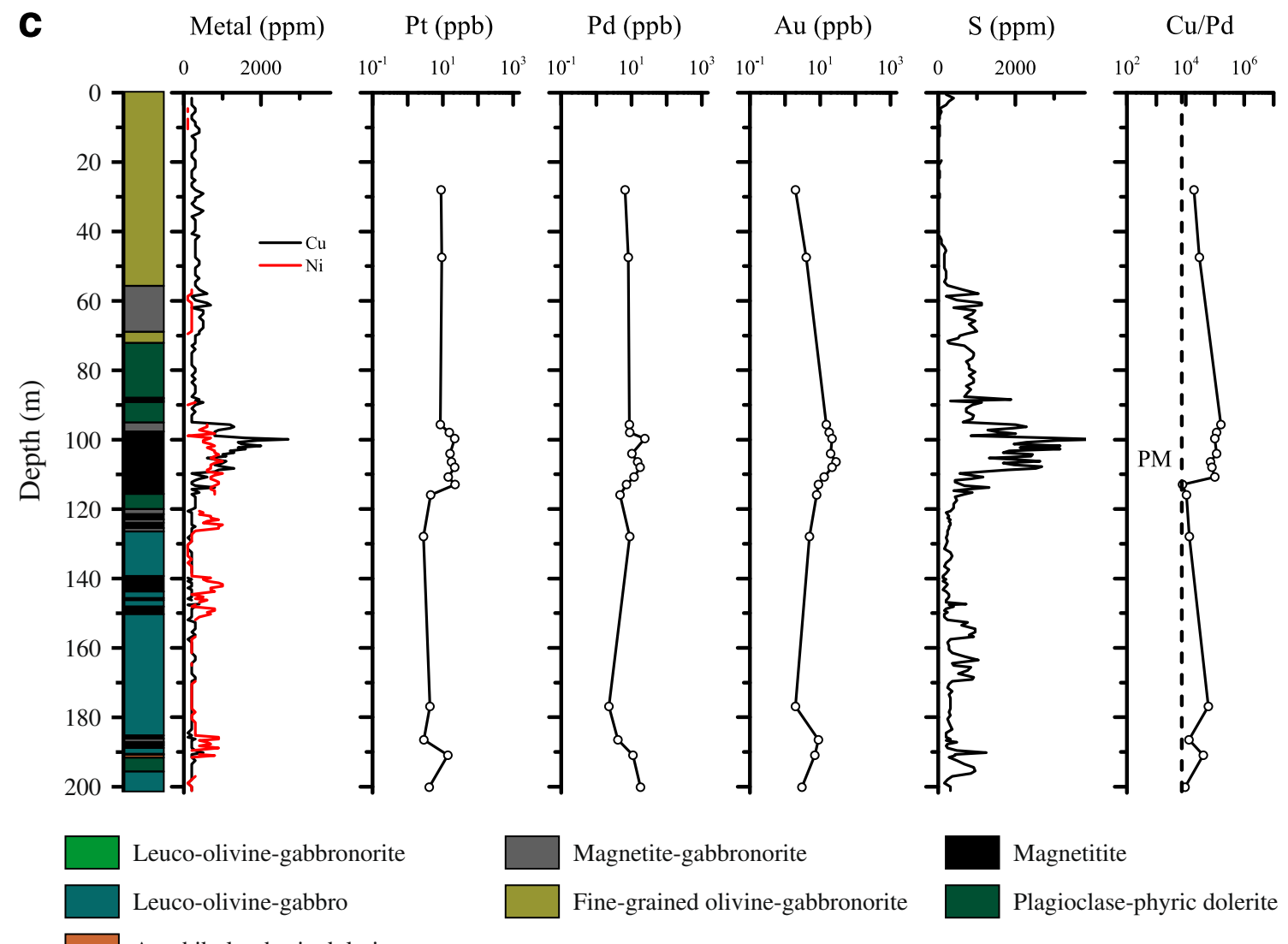

Fig. 10 (continued)

enriched intersection. The correlation between $\mathrm{Cu}$ and $\mathrm{Pd}$ is much less clear indicating that $\mathrm{Pd}$ is not directly associated with $\mathrm{Cu}$ or $\mathrm{S}$ (Fig. 11b). The samples can be broadly subdivided into a group with high $\mathrm{Cu}$ and low $\mathrm{Pd}$ and another group with low $\mathrm{Cu}$ and high Pd. Similar trends have also been reported for the Stella intrusion in South Africa (Maier et al. 2003). Notably, all mineralised samples from the Jameson Range have Pt/Pd ratios above unity (Fig. 11c). The spatial association of PGE enrichment and magnetitite occurrence is also expressed in a plot of $\mathrm{V}$ (as a proxy for magnetite) vs. $\mathrm{Pt}+$ Pd (Fig. 11d). A broad correlation between these elements is evident, especially among the samples with the highest PGE concentrations.

Chalcophile and platinum-group element concentrations of two PGE-rich magnetitites from drill holes WMTD5 and TMD002, respectively, are given in ESM 2: Table S2. The primitive mantle-normalised chalcophile element pattern shows a strong enrichment of palladium-group PGE (PPGE: $\mathrm{Rh}, \mathrm{Pt}, \mathrm{Pd}$ ) over iridium-group PGE (IPGE: Os, Ir, Ru) in the Jameson Range magnetitites (Fig. 12). Normalised Ni values are considerably lower than Ir and to a lesser extent $\mathrm{Ru}$, whereas $\mathrm{Rh}, \mathrm{Pt}, \mathrm{Pd}, \mathrm{Au}$ and $\mathrm{Cu}$ have much higher normalised values. Moreover, $\mathrm{Pt}$ is enriched over Pd with a minor positive Au anomaly. In comparison to the Main Magnetite Layer from the Bushveld Complex described by Barnes et al. (2004), all chalcophile elements are significantly elevated in the basal magnetitite. In contrast, the Upper Main Reef from the Stella intrusion shows a broadly similar chalcophile element pattern with an enrichment in PPGE over IPGE; however, Rh appears to be depleted in the Upper Main Reef (Maier et al. 2003). Further, $\mathrm{Pt} / \mathrm{Pd}$ ratios and $\mathrm{Au}$ concentrations are higher in the Stella magnetitites.

\section{Note on metal enrichment in P-rich layers}

The available information on phosphorus enrichment in the Jameson Range intrusion is solely based on geochemical assays from WMC Resources Ltd (2001) as none of the enriched zones were sampled for whole rock and trace element geochemical analysis or thin sections. The P-rich layers vary from 1 to $59 \mathrm{~m}$ in thickness containing on average between 0.8 and $1.5 \mathrm{wt} \% \mathrm{P}_{2} \mathrm{O}_{5}$. Individual $1 \mathrm{~m}$ samples from these layers may reach up to $2.9 \mathrm{wt} \% \mathrm{P}_{2} \mathrm{O}_{5}$ (Fig. 5). The thickest layer is covered by less than $10 \mathrm{~m}$ of overburden, and the mineralised 
a

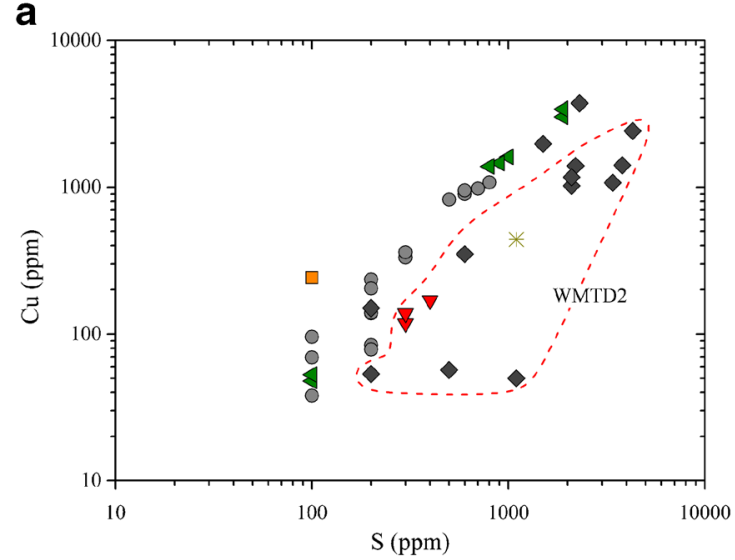

C

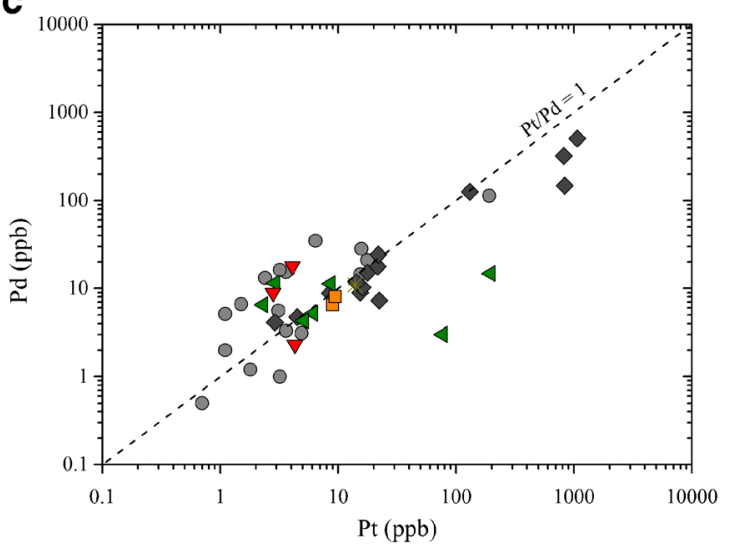

b

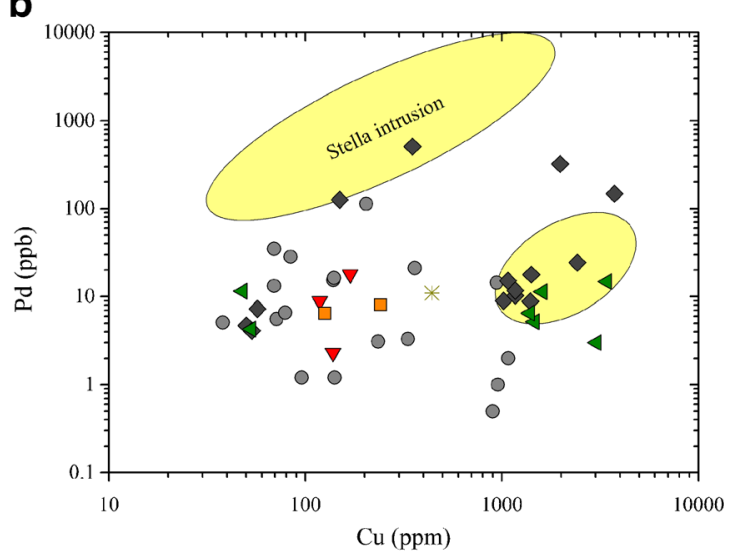

d

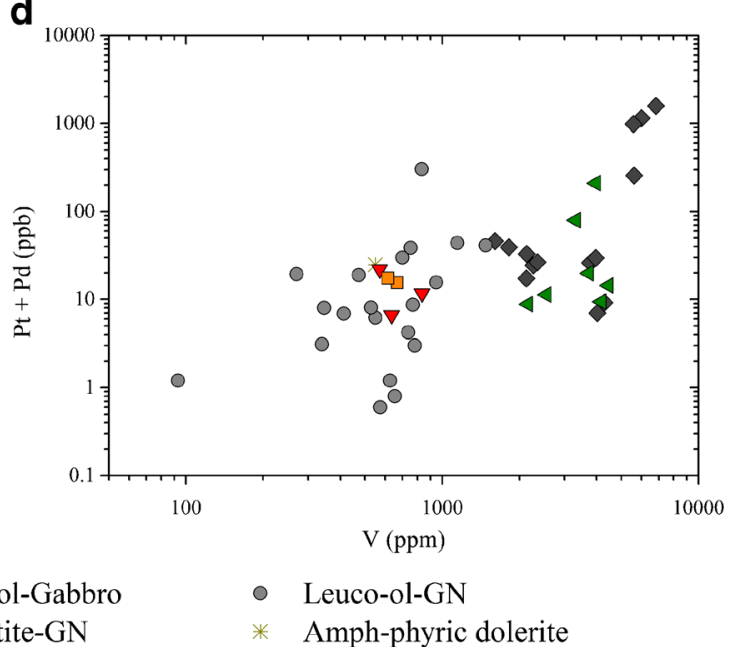

Fig. 11 Binary variation diagram of different chalcophile element and V. a $\mathrm{Cu}$ vs. S. b Pd vs. Cu. c Pd vs. Pt. d Pt + Pd vs. V. Note the broadly positive correlation between the $\mathrm{Pt}+\mathrm{Pd}$ and V. Data from the Stella

zone comprises at least $59 \mathrm{~m}$ as the drill hole did not intersect the bottom of the layer. Hence, the horizon may potentially

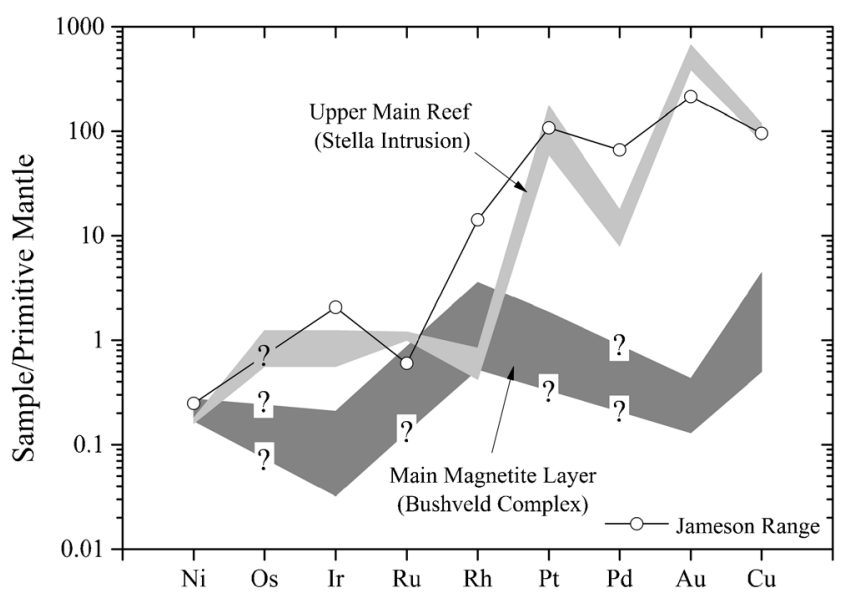

Fig. 12 Primitive mantle-normalised chalcophile element pattern of the PGE-rich basal magnetitite from the Jameson Range. Stella intrusion and Bushveld Complex data are from Maier et al. (2003) and Barnes et al. (2004), respectively. Normalisation values are taken from Barnes and Maier (1999). Metal concentrations are given in ESM 2: Table S2
Intrusion are taken from Maier et al. (2003). Abbreviations: $G N=$ gabbronorite, $o l=$ olivine, $a m p h=$ amphibole

extend further downhole. The $\mathrm{TiO}_{2}$ concentrations of the $\mathrm{P}$ rich intersections are generally low, at 3 to $6 \mathrm{wt} \%$, whereas $\mathrm{Fe}_{2} \mathrm{O}_{3}$ concentrations mostly range from 16 to $21 \mathrm{wt} \%$. The $\mathrm{V}_{2} \mathrm{O}_{5}$ contents in these layers are extremely low, at less than $0.1 \mathrm{wt} \%$. Based on the Mg\#, the entire succession becomes gradually more evolved towards the top of the intrusion. An overview of the highest mineralised intersections is provided in ESM 2: Table S3.

\section{Discussion}

Due to the limited available information on the stratigraphy of the Jameson Range intrusion, the first part of the discussion is concerned with the stratigraphy of the intrusion regarding the correlation between drill holes and potential structural duplication in response to faulting. The second part aims at the comparison of the Jameson Range intrusion with well-studied layered intrusions emphasising potential formation mechanisms of layering before concluding with implications for further mineral exploration. 


\section{Stratigraphic relationship between drill holes WMTD5 and WMTD2}

The Jameson Range intrusion dips at about $20^{\circ}$ to $30^{\circ}$ to the southwest; therefore, the succession is younging to the southwest. Considering the location of drill hole WMTD2 relative to WMTD5 and TMD002, it would follow that the PGE-poor magnetitite from drill hole WMTD2 is located stratigraphically below the basal magnetitite (Figs. 1 and 2). However, the close proximity of the WMTD2 magnetitite to a P-rich layer suggests that the magnetitite is located stratigraphically above the basal magnetitite (cf. Fig. 2). Magnetite with significantly higher $\mathrm{Cr}$ and $\mathrm{V}$ concentrations from drill hole WMTD5 (Fig. 7b) provides further support for this interpretation as $\mathrm{Cr}$ concentrations generally show a rapid depletion with height (Cawthorn and McCarthy 1980). Moreover, the major element composition of the WMTD2 magnetitite resembles that of some of the upper magnetitites with relatively high $\mathrm{Fe} / \mathrm{Ti}$ ratios described by Maier et al. (2014). In addition, the lithologies intersected in drill hole WMTD2 have relatively high $\mathrm{Cu} / \mathrm{Pd}$ ratios suggesting crystallisation from a PGE-depleted magma which is also supported by the low PGE concentrations of the magnetitite (Fig. 10c). In contrast, the $\mathrm{Cu} / \mathrm{Pd}$ ratio of the basal magnetitite from drill holes WMTD5 and TMD002 is significantly lower (Fig. 5). Hence, there are several lines of evidence suggesting that drill hole WMTD2 intersected lithologies above the basal magnetitite.

Notably, the magnetitite from drill hole WMTD2 is characterised by a distinct magnetic signature compared to the magnetitites in the vicinity of drill holes WMTD5 and TMD002 (Fig. 2). The latter can be traced for several kilometres along strike, whereas the former has a rather diffuse magnetic response with a limited horizontal extent. We interpret this to reflect strong tectonic disturbance of the magnetite layer resulting in the formation of several blocks. As a consequence, we propose that the upper part of the Jameson Range was duplicated by faulting. The fault type and its geometry cannot be further constrained based on the present data. The model would explain the unusual stratigraphic thickness of the Jameson Range, which is thought to be up to $10 \mathrm{~km}$ (Maier et al. 2014). Alternatively, the lithologies intersected in drill holes WMTD5 and TMD002 could represent a fresh influx of PGE undepleted magma. However, the location of the WMTD2 magnetitite coupled with tectonic lineaments inferred from the total magnetic map strongly suggests otherwise.

The fine-grained olivine-gabbronorite intersected in the upper part of drill hole WMTD2 seemingly hosts a magnetiterich zone of up to $15 \mathrm{~m}$ (Fig. 10c). The Geological Survey of Western Australia mapped the area around the drill hole as "Mummawarrawarra Basalt" belonging to the "Kunmarnara Group", which predates the intrusion of the layered maficultramafic Giles Complex (Fig. 1). Two Mummawarrawarra Basalt samples (GSWA Nos. 185634 and 185635) described by Howard et al. (2011a) show strongly fractionated REE patterns with $\mathrm{La} / \mathrm{Yb}_{\mathrm{N}}=3.8-4.5$, whereas the fine-grained olivine-gabbronorite has $\mathrm{La} / \mathrm{Yb}_{\mathrm{N}}<2.8$. Therefore, it seems rather unlikely that this rock type represents a subvolcanic equivalent of the Mummawarrawarra Basalt. This is supported by the low $\mathrm{Zr}$ concentrations ( $41 \mathrm{ppm} \mathrm{Zr,} \mathrm{Fig.} 8$ ) of the finegrained olivine-gabbronorite indicating a cumulus origin of the rock type. On the basis of olivine compositions, it must have crystallised from a highly evolved magma (Fig. 6a). However, plagioclase and pyroxene compositions are only slightly more evolved than in the cumulus rocks underlying the fine-grained olivine-gabbronorite. Accordingly, the rock type potentially represents an evolved equivalent of the underlying cumulus rock types. It could be interpreted as a lithology containing evolved cumulus olivine in a fine-grained matrix of plagioclase and pyroxene possibly crystallising from a residual magma at relatively high cooling rates. Alternatively, olivine compositions were significantly modified by trapped liquid reactions resulting in a shift to apparently more evolved compositions (Barnes 1986). The occurrence of a considerably coarser-grained magnetite-rich zone within the finegrained olivine-gabbronorite is discussed later.

\section{Comparison with other layered intrusions}

In comparison to the Bushveld Complex of South Africa (Teigler and Eales 1996; Roelofse and Ashwal 2012; Barnes' unpublished data), olivine from the Jameson Range crystallised from a significantly more evolved magma than olivine from the Lower Zone (Fig. 6a). Moreover, plagioclase and orthopyroxene compositions indicate that the Jameson Range is broadly equivalent to the most evolved parts of the Main Zone or the lower part of the Upper Zone of the Bushveld Complex (Fig. 6b). Magnetite from the Jameson Range is highly enriched in $\mathrm{Fe}, \mathrm{V}$ and $\mathrm{Cr}$ relative to magnetite from the well-studied Emeishan layered intrusions in SW China described by Liu et al. (2015). Moreover, the highest $\mathrm{V}$ concentrations in magnetite from the Upper Zone of the Bushveld Complex ( 10,000 ppm V, Tegner et al. 2006) are also lower than in magnetite from the Jameson Range (Fig. 7b). The highest $\mathrm{Cr}$ concentrations in magnetite from the Emeishan layered intrusion were reported for the Hongge intrusion which hosts a number of magnetite layers in clinopyroxenites rather than gabbroic rocks (Bai et al. 2012). The compositional range of the Jameson Range magnetite clearly suggests a magmatic origin of magnetite. Tegner et al. (2006) showed that the V concentrations in magnetite from the Upper Zone of the Bushveld Complex decrease dramatically with stratigraphic height, whereas $\mathrm{V}$ concentrations in magnetite from the Emeishan layered intrusions decrease gradually (Fig. 7b, c). Hence, the evolution of the magnetite chemistry in the Jameson Range strongly resembles that of the Bushveld Upper Zone. 
In the Bushveld Complex, P-rich layers occur together with a suite of magnetitites in the upper third of the Upper Zone (e.g. Cawthorn et al. 2006). Tegner et al. (2006) reported six nelsonite (magnetite-ilmenite-apatite) layers within the western Bushveld Complex, some of which are currently being explored in the northern limb of the Bushveld as they could have economic significance. In the Jameson Range, P-rich layers already occur in the lower half of the Upper Zone, i.e. at a lower stratigraphic level than in the Bushveld Complex. Their P grade is significantly lower than that of the nelsonites from the Bushveld Complex, but the relatively poor exposure constitutes significant added exploration potential.

Another remarkable occurrence of massive magnetite layers hosted by an Emeishan layered intrusion is the gabbroic Panzhihua intrusion (Zhou et al. 2005; Zhou et al. 2013). Multiple lenses and layers of massive magnetite in layered (melano-)gabbro occur in the lower portion of the intrusion. Zhou et al. (2005) reported up to $0.87 \mathrm{wt} \% \mathrm{~V}_{2} \mathrm{O}_{5}$ and $15.5 \mathrm{wt} \% \mathrm{TiO}_{2}$, respectively, which is significantly lower compared to the PGE-rich magnetitite from the Jameson Range. However, $\mathrm{P}_{2} \mathrm{O}_{5}$ concentrations in the Panzhihua intrusion are comparable with up to $2.59 \mathrm{wt} \%$.

In some cases, magnetite-rich lithologies in the upper parts of layered intrusions also show an enrichment in PGE. Globally, this reef-type PGE mineralisation can be broadly subdivided into two groups: (1) PGE mineralisation hosted by magnetitites, such as in the Stella intrusion in South Africa (Maier et al. 2003), the Rio Jacaré intrusion in northeastern Brazil (Sá et al. 2005), the Coldwell Complex in Ontario (Barrie et al. 2002) and the Bushveld Complex (von Gruenewaldt 1976), and (2) PGE mineralisation in magnetitegabbros, such as the Koitelainen intrusion in northern Finland (Mutanen 1997), the Rincón del Tigre intrusion in Bolivia (Prendergast 2000), the Sonju Lake intrusion in Minnesota (Joslin 2004) and perhaps the Skaergaard intrusion in east Greenland, even though in the latter the spatial association to magnetite enrichment is not as clear (Andersen et al. 1998; Holwell and Keays 2014).

All of these reefs are characterised by relatively low modal abundances of sulphides, reaching 1 to $2 \%$ at most. The mineralogy of the mineralisation is also exceptional as most of the intrusions, except for Rio Jacaré and Stella, are dominated by $\mathrm{Cu}$-rich sulphides with high $\mathrm{Cu} / \mathrm{Fe}$ ratios, including bornite and chalcopyrite, whereas pyrrhotite is often absent. The only other known magmatic occurrence of bornite hosted by mafic-ultramafic lithologies is in the Okiep district of Namaqualand, South Africa (Cawthorn and Meyer 1993; Maier 2000). Another important characteristic of the PGEmineralised magnetitites is the Ni depletion which is generally attributed to the prolonged fractionation of olivine and pyroxene prior to sulphur saturation (Leeman and Lindstrom 1978). Geochemically, these reefs can be recognised by a sharp increase in $\mathrm{Cu} / \mathrm{Pd}$ ratios above the PGE-rich interval and $\mathrm{Pt} /$ Pd ratios mostly above unity.

The basal magnetitite from the Jameson Range exhibits very similar characteristics in terms of mineralogy and geochemistry compared to the reefs described above (Figs. 4 and 10a, b). Hence, the Jameson Range magnetitite meets all criteria to be considered a "Stella-type" reef as defined by Maier et al. (2003). In contrast, the magnetitite intersected in drill hole WMTD2 exhibits no enrichment in PGE and the mineralogy is dominated by a typical magmatic sulphide assemblage comprising pyrrhotite, chalcopyrite and minor pentlandite.

\section{Formation of PGE mineralisation}

It is generally accepted that the formation of reef-type PGE deposits in the upper parts of layered intrusions is closely linked to sulphur saturation and the associated concentration of chalcophile elements into an immiscible sulphide liquid (e.g. Maier 2005). Maier et al. (2014) showed that the sulphur isotopic composition of Jameson Range samples mostly plots close to the mantle range suggesting predominantly mantlederived sulphur. This interpretation is further supported by $\mathrm{Sr}$ and $\mathrm{Nd}$ isotopic compositions in the mantle range as well as low $\mathrm{Th}$ and $\mathrm{Zr}$ concentrations in the magnetite-poor lithologies indicating little crustal contamination of the magma that produced the Jameson Range (Maier et al. 2014). As a result, sulphur saturation is likely to have occurred in response to extensive fractionation and the crystallisation of magnetite leading to a decrease in the $\mathrm{Fe}^{2+}$ activity, which lowered the sulphur solubility of the magma. The sulphide liquid scavenged the remaining chalcophile elements from the overlying magma, which is reflected in the elevated $\mathrm{Cu} / \mathrm{Pd}$ ratios above the basal magnetitite (Fig. 10a, b). The correlation between $\mathrm{V}$ as a proxy for magnetite and $\mathrm{Pt}+\mathrm{Pd}$ could be taken as further evidence for the importance of magnetite crystallisation in promoting sulphur saturation (Fig. 11d). The high degree of fractionation is not only evident in the evolved mineral chemistry but also in the low mantle-normalised $\mathrm{Ni} / \mathrm{Ir}$ ratios ranging from 0.09 to 0.17 in the basal magnetitite (Fig. 12).

Another important aspect of the PGE-mineralised magnetitite from the Jameson Range is the vertical metal distribution exhibiting a stratigraphic separation of the PGE peak from the $\mathrm{Cu}$ peak (Fig. 13). The highest concentrations of $\mathrm{Pt}$ and $\mathrm{Pd}$ are offset by about $1 \mathrm{~m}$ from the $\mathrm{Cu}$ peak, whereas the highest $\mathrm{Au}$ concentrations occur between the $\mathrm{Cu}$ and Pt peaks. An offset between Pt and Pd is not apparent, but this may be attributed to the sampling resolution. Many other PGE reeftype occurrences show a similar offset metal distribution, such as the Munni Munni Complex in Western Australia, the Great Dyke in Zimbabwe, the Stella intrusion, the Skaergaard intrusion and the Rincón del Tigre intrusion (Barnes 1993; Naldrett and Wilson 1990; Maier et al. 2003; Holwell and Keays 2014; Prendergast 2000). The characteristic separation of peaks has 
Fig. 13 Detailed stratigraphic log of the basal magnetite layer together with the vertical metal distribution intersected in drill hole WMTD5. Note that $\mathrm{Fe} / \mathrm{Ti}$ ratios decrease upwards within the magnetitite and that peak $\mathrm{Cu}$ concentrations are offset from the highest PGE concentrations. Green = leuco-olivinegabbronorite, grey = magnetitegabbronorite, black = magnetitite

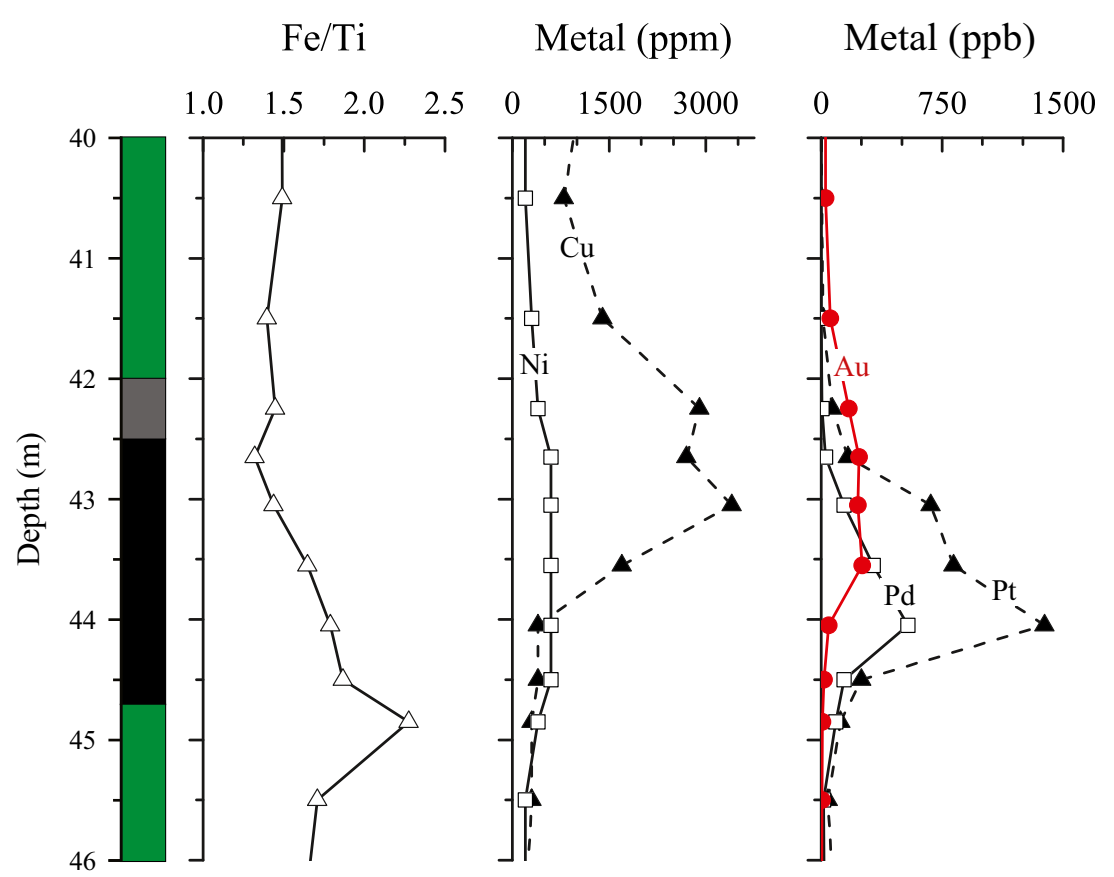

been interpreted to be the result of Rayleigh fractionation of the sulphide melt in conjunction with different effective partition coefficients between sulphide liquid and silicate magma (Barnes et al. 1993). Due to the extremely high partition coefficients of PGE into the sulphide liquid, the first sulphide droplets to settle would have had much higher PGE tenors than the following sulphides. According to Wilson and Tredoux (1990), the partition coefficients decrease in the order $\mathrm{Pd}>\mathrm{Pt}>\mathrm{Au}>\mathrm{Cu}$. This sequence of chalcophile elements is also reflected in the vertical metal distribution of the basal magnetitite, which strongly suggests that the distribution pattern is mainly controlled by partition coefficients.

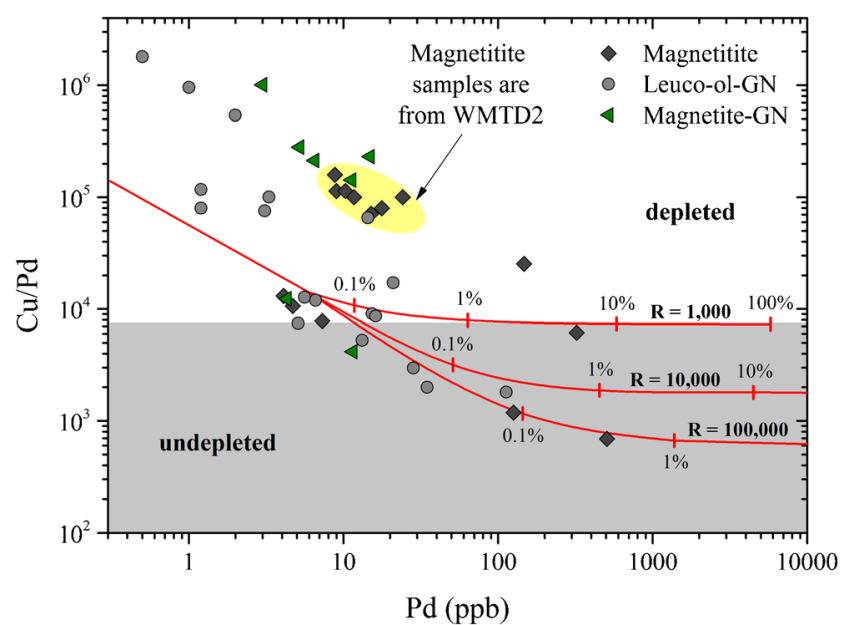

Fig. 14 Plot of $\mathrm{Cu} / \mathrm{Pd}$ vs. Pd for samples from the Jameson Range intrusion. The tie lines represent model sulphides crystallising from a slightly metal-depleted picritic melt (removal of $0.002 \%$ sulphides) at $R$ factors ranging from 1000 to 100,000 . See text for explanation. Abbreviations: $G N=$ gabbronorite, $o l=$ olivine
The conditions of sulphide formation can provide further insight into the processes leading to the PGE enrichment in the basal magnetitite. Figure 14 shows that most of the PGE-rich samples have $\mathrm{Cu} / \mathrm{Pd}$ ratios below the primitive mantle value of 7500 (Barnes and Maier 1999). Another group of rather PGEpoor samples has considerably higher $\mathrm{Cu} / \mathrm{Pd}$ ratios. Because chilled margins have not been documented so far for the Jameson Range intrusion, the parental magma composition remains rather elusive. Therefore, we assume that the parental magma had a composition similar to a typical picritic melt (Barnes and Lightfoot 2005). In order to model the samples with relatively low $\mathrm{Cu} / \mathrm{Pd}$ ratios at low $\mathrm{Pd}$ concentrations, a small amount of sulphides must have been removed from the undepleted picritic melt (ca. $0.002 \%$ sulphides). Modelling of the PGE-rich samples indicates that sulphide segregation occurred at very high $R$ factors close to 100,000 . The validity of the model is further supported by the low sulphide fraction necessary to accommodate 100 to $600 \mathrm{ppb} \mathrm{Pd}$ as the PGE-rich parts of the basal magnetitite mostly contain less than 1 vol\% sulphides. In contrast, most of the magnetitite samples from drill hole WMTD2 have much higher $\mathrm{Cu} / \mathrm{Pd}$ ratios strongly suggesting sulphide segregation from a PGE-depleted magma. The high $R$ factors of the PGE-rich samples require that the sulphide droplets equilibrated with large amounts of silicate magma in order to reach such high PGE tenors. In comparison, high $R$ factors are generally characteristic of PGE-dominated deposits, such as the Merensky Reef and the UG2 (cf. Barnes et al. 1993).

\section{Formation of magnetite layers}

The formation of magnetitites remains controversial. Maier et al. (2013) provided a review of the potential models of 
formation. In essence, these models envisage pressure changes (Cameron 1980; Cawthorn and McCarthy 1980; Lipin 1993), changes in oxygen fugacity induced by contamination or magma addition and mixing (Ulmer 1969), liquid immiscibility of an iron-rich oxide melt (Naslund 1983), density currents of crystal slurries that sweep down the chamber walls (Irvine et al. 1998) and crystal sorting of oxide-silicate slurries (Maier et al. 2013) resulting in the accumulation of Fe-Ti oxides to form a massive layer.

The remarkable lateral continuity of the basal magnetitite in the Jameson Range over at least $19 \mathrm{~km}$ casts doubt on the feasibility of contamination models. Mineral compositions, chalcophile elements and $\mathrm{Sr}$ isotopic compositions of plagioclase from the Jameson Range reported by Maier et al. (2014) do not support the model of magma chamber replenishment. The liquid immiscibility model remains controversial as experimental studies have largely failed to produce Fe-rich oxide liquids using compositions close to natural basalts and diorites (Toplis and Carroll 1996). Moreover, Eales and Cawthorn (1996) argued that an immiscible Fe-oxide liquid would not form sharp planar bottom contacts due to the low viscosity and high density of the liquid.

Layers characterised by a well-defined base with high modal abundances of dense dark minerals gradually passing into a rock type with increasing amounts of less dense feldspar led Wager and Brown (1968) to propose that the crystals settled gravitationally according to their densities. Even though this very early model has been previously rejected based on the presence of largely unlayered domains, its validity shall be tested here on the basal magnetitite. Accordingly, the lowermost parts of the magnetitite should have the highest densities, which would be reflected in the abundance of minerals of high density. As MLA-XMOD measurements indicate that 96 to 98 vol\% of the 2- to 3-m-thick layer consist of Fe-Ti oxides, the small proportion of silicates does not significantly affect the density of the rock type. In terms of mineral densities, magnetite has a slightly higher density $\left(5.15 \mathrm{~g} / \mathrm{cm}^{3}\right)$ compared to ilmenite $\left(4.72 \mathrm{~g} / \mathrm{cm}^{3}\right)$. As a result, Fe/Ti ratios can be used as an indirect proxy for rock densities. High amounts of dense magnetite would produce high $\mathrm{Fe} / \mathrm{Ti}$ ratios, whereas increasing amounts of ilmenite would progressively lower the ratio. Figure 13 shows that the $\mathrm{Fe} / \mathrm{Ti}$ ratio decreases with height across the basal magnetitite and its immediate host rocks.

Other dense minerals within evolved magmatic successions include zircon and potentially baddeleyite, both of which are Zr-rich minerals. The density of zircon and baddeleyite is 4.65 and $5.75 \mathrm{~g} / \mathrm{cm}^{3}$, respectively. Hence, $\mathrm{Zr}$ concentrations should be elevated in the magnetitite, especially in the ilmenite-rich parts due to similar densities of ilmenite and zircon. Figure $6 \mathrm{~d}$ clearly shows that samples with high amounts of $\mathrm{Fe}$ - $\mathrm{Ti}$ oxides and therefore low $\mathrm{MgO}$ concentrations are the ones with the highest $\mathrm{Zr}$ concentrations. Further, $\mathrm{TiO}_{2}$ shows a very well-defined positive correlation with $\mathrm{Zr}$

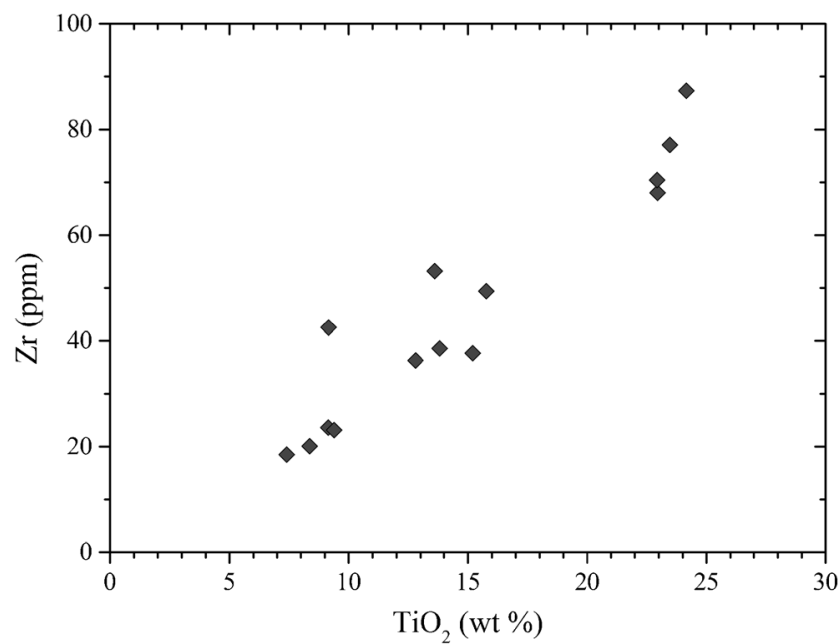

Fig. 15 Plot of $\mathrm{Zr}$ vs. $\mathrm{TiO}_{2}$ for magnetitites from the Jameson Range. Note the well-defined positive correlation between these elements

$\left(R^{2}=0.89\right)$ possibly suggesting a process that results in the coaccumulation of ilmenite and zircon in distinct layers (Fig. 15). The high $\mathrm{Zr}$ concentrations in the magnetitites could also reflect high abundances of $\mathrm{Zr}$ in ilmenite. For instance, the Taihe layered intrusion in SW China hosts ilmenite with $76 \pm 31 \mathrm{ppm} \mathrm{Zr}(n=47)$ (She et al. 2015). A recent study of mafic systems by Klemme et al. (2006) using synthetic basaltic melt compositions indicated that the partition coefficient for $\mathrm{Zr}$ into ilmenite is rather low with $0.70 \pm 0.10 \quad(n=4)$. Ewart and Griffin (1994) also reported low partition coefficients of $1.07 \pm 0.58(n=8)$. Only one high-silica rhyolite sample produced $\mathrm{Zr}$-rich ilmenite with a partition coefficient of 10.4. The magnetitite with the highest $\mathrm{Zr}$ concentration ( 90 ppm Zr, Fig. 15) contains approx. 45 vol\% ilmenite. Assuming $75 \mathrm{ppm} \mathrm{Zr}$ in ilmenite, similar to the mean $\mathrm{Zr}$ concentrations in ilmenite from the Taihe layered intrusion, the $\mathrm{Zr}$ concentration accounted for by this mineral would be less than $35 \mathrm{ppm}$, although the magnetitite contains almost $90 \mathrm{ppm} \mathrm{Zr}$. Therefore, it is difficult to explain the total $\mathrm{Zr}$ budget of the sample with the presence of ilmenite. Alternatively, it could be argued that the magnetitites contain high amounts of trapped liquid; however, incompatible trace element patterns suggest otherwise (Fig. 9c). Assuming that an immiscible Fe-oxide liquid could potentially form in a magma chamber to produce magnetitites, the enrichment in $\mathrm{Zr}$ within these layer should thus be controlled by the partition coefficient (D) of $\mathrm{Zr}$ between Fe-rich and Si-rich melts. However, the Zr partition coefficients determined by Veksler et al. (2006) show highly erratic behaviour of $\mathrm{Zr}$ ranging from $D=0.90$ to 1.87 into the Fe-rich liquid. Hence, experimental data do not explain the high $\mathrm{Zr}$ concentrations characteristic of magnetitites from the Jameson Range.

On the basis of Wager and Brown's (1968) model for the Skaergaard intrusion in East Greenland, Irvine et al. (1998) proposed episodic density currents of crystal slurries sweeping down the chamber walls to produce modally graded cumulate 
layers. According to Maier et al. (2013), the model is not entirely satisfactory as it cannot explain the abundant, highly elongated, sub-horizontally orientated anorthosite autoliths often associated with magnetite layers. Moreover, the above-described Rayleightype metal distribution patterns observed in many PGE reefs cannot be explained by turbulent density currents. In order to resolve this issue, Maier et al. (2013) suggested crystal sorting of oxide-silicate slurries, somewhat similar to the model proposed by Irvine et al. (1998), but envisaging a process analogous to sorting of raisins in a gently shaken box of cornflakes, where the raisins accumulate at the bottom preserving their relative position to each other. Accordingly, the Rayleigh-type metal distribution in the reefs would be preserved.

The effect described by Maier et al. (2013) is known as the "Brazil-nut effect", which is mainly governed by the grain size of the involved particles (Möbius et al. 2001). The coarse-grained particles tend to rise, whereas smaller grains accumulate at the bottom. In contrast, our study indicates that the formation of magnetitites is mainly controlled by mineral densities, although the grain size also affects the sorting process to a certain extent.

Hence, we propose a slightly modified version of crystal slurries in magmatic systems. Crystal sorting of slumping oxide-silicate slurries seems to occur on all scales in layered intrusion. Rather than grain size-dependent sorting ("Brazil-nut effect"), these slurries produce density-sorted layers with high density minerals at the bottom. The mechanism is somewhat similar to gravity concentration in a jig circuit used in cassiterite, tungsten, gold and iron ore processing (Wills 2006). According to the author, a pulsating water current produces stratification of a feed resulting in the separation of minerals with different densities under hindered settling conditions. In fact, smaller and heavier mineral grains co-accumulate with larger and lighter ones. Therefore, a jig circuit could represent an analogue to slumping crystal slurries in layered intrusions where the bottom of individual layers is enriched in dense minerals like magnetite, ilmenite and zircon with gradually increasing amounts of less dense silicates towards the top.

In a first-order approximation, relatively small magnetite $\left(\rho=5.15 \mathrm{~g} / \mathrm{cm}^{3}\right)$ grains could accumulate together with larger olivine and pyroxene $\left(\rho=3.30 \mathrm{~g} / \mathrm{cm}^{3}\right)$ grains in a distinct layer. The magnetitite from drill hole WMTD2 contains abundant olivine inclusions that are considerably larger than the co-existing Fe-Ti oxides (Fig. 3c). This observation is somewhat expected in a density-sorted system. However, one of the magnetite-rich layers is entirely hosted by the fine-grained olivine-gabbronorite containing considerably smaller-sized olivine crystals than the magnetite-rich zone. This can be explained by slumping of a semi-consolidated gabbronoritic, perhaps troctolitic, magnetitebearing proto-cumulate to produce a crystal slurry that underwent sorting and subsequently injected into the semi-consolidated fine-grained olivine-gabbronorite. Notably, this model explains several observations: (1) the presence of a thin magnetitite at the base of the magnetite-rich zone, (2) the anomalously high Fo content in olivine from the magnetite-rich zone and (3) the presence of much coarser-grained magnetite-rich lithologies enclosed in fine-grained olivine-gabbronorite.

\section{Implications on prospectivity}

The basal magnetite layer of the Jameson Range may potentially represent a future PGE-Au-V-Ti resource. With up to $2 \mathrm{ppm} \mathrm{Pt}+\mathrm{Pd}+\mathrm{Au}, 1.05 \mathrm{wt} \% \mathrm{~V}_{2} \mathrm{O}_{5}$ and $24 \mathrm{wt} \% \mathrm{TiO}_{2}$, the layer could be an interesting target for exploration for a polymetallic resource. Precious metal and V concentrations seem to be consistent among the analysed drill holes. This is supported by PepinNini Minerals Ltd (2015) surface analysis of the magnetitite yielding up to $2.45 \mathrm{ppm}$ PGE + Au. However, better definition of the magnetitite thickness along strike is required in order to estimate the total PGE resource. For comparison, Bushveld Minerals Ltd (2014) is currently planning to mine the Main Magnetite Layer in the Bushveld Complex reaching a combined thickness of $7.68 \mathrm{~m}$ with $1.48 \mathrm{wt} \% \mathrm{~V}_{2} \mathrm{O}_{5}$ and no PGE. In terms of mineral processing, the MLA-GXMAP image (ESM 1: Fig. S1) of the magnetitite indicates that some of the Ti is present in discrete ilmenite crystals rather than being entirely hosted by exsolution lamellae in titanomagnetite. Therefore, some of the contained Ti could also be extracted from the magnetitite. Apart from the PGE-rich magnetitite, phosphate has the potential to represent an additional commodity of interest within in the Jameson Range. By analogy from other layered intrusions like the Bushveld Complex, nelsonites could be potentially present. However, further exploration and research is clearly needed in the Jameson Range in order to constrain its full mineral potential.

\section{Conclusion}

1. The Jameson Range intrusion as part of the Mantamaru Intrusion mainly comprises leucocratic olivine-bearing, Fe-Ti oxide-rich cumulates with several magnetite layers.

2. The upper part of the Jameson Range intrusion hosts several P-rich layers reaching at least $59 \mathrm{~m}$ in thickness.

3. The basal magnetite layer in the Jameson Range is markedly enriched in PGE with up to $2 \mathrm{ppm} \mathrm{Pt}+\mathrm{Pd}+\mathrm{Au}$ and $0.3 \mathrm{wt} \% \mathrm{Cu}$ representing a Stella-type PGE reef with further potential for significant Ti-V mineralisation. Average $\mathrm{TiO}_{2}$ and $\mathrm{V}_{2} \mathrm{O}_{5}$ concentrations in the basal magnetite layer are 24 and $1.05 \mathrm{wt} \%$, respectively.

4. Sulphide saturation was likely reached in response to extensive fractionation and magnetite crystallisation resulting in high tenor PGE mineralisation at $R$ factors between 10,000 and 100,000.

5. The intersected magnetitites provide evidence for the injection of crystal slurries into unconsolidated cumulates. The principle sorting process within these slurries is not so much 
controlled by the grain size-dependent "Brazil-nut effect" but rather by mineral densities and their sorting velocities, although the grain size also affects the sorting process.

6. Several lines of evidence suggest that faulting duplicated the igneous succession, which would account for the unusual stratigraphic thickness of up to $10 \mathrm{~km}$.

7. The discovery of P-rich layers in the Jameson Range significantly contributes to the mineral potential of the Musgrave Province. Further exploration will result in a better definition of the PGE-Au-V-Ti-P mineralisation potential associated with the Jameson Range intrusion. The development of the Nebo-Babel deposit close-by might establish an infrastructure providing favourable conditions for exploration in the near future.

\begin{abstract}
Acknowledgments Anglo American Exploration (Australia) Pty Ltd is gratefully thanked for funding and supporting this M.Sc. project. Special thanks go to Kirsty Culver and Josephine Tobin for their great assistance in the Musgrave Province. Fiona Best is thanked for thoughtful reviews of earlier versions of parts of this manuscript. We thank Bernhard Schulz, Kai Bachmann, Tobias Höfig, Andreas Bartzsch and the whole group at TU Bergakademie Freiberg and Helmholtz Institute Freiberg for Resource Technology for their help with sample preparation and analytical work. We are also grateful to an anonymous reviewer and Rais Latypov for their constructive reviews. Marco Fiorentini is thanked for his editorial handling.
\end{abstract}

Open Access This article is distributed under the terms of the Creative Commons Attribution 4.0 International License (http:// creativecommons.org/licenses/by/4.0/), which permits unrestricted use, distribution, and reproduction in any medium, provided you give appropriate credit to the original author(s) and the source, provide a link to the Creative Commons license, and indicate if changes were made.

\section{References}

Andersen JCØ, Rasmussen H, Nielsen TFD, Ronsbo JG (1998) The Triple Group and the Platinova gold and palladium reefs in the Skaergaard Intrusion; stratigraphic and petrographic relations. Econ Geol 93:488-509

Bai ZJ, Zhong H, Naldrett AJ, Zhu WG, Xu GW (2012) Whole-rock and mineral composition constraints on the genesis of the Giant Hongge Fe-Ti-V oxide deposit in the Emeishan Large Igneous Province, Southwest China. Econ Geol 107:507-524

Baker PM, Waugh RS (2005) The role of surface geochemistry in the discovery of the Babel and Nebo magmatic nickel-copper-PGE deposits. Geochem Explor Environ Anal 5:195-200

Ballhaus CG, Glikson AY (1995) The petrology of layered maficultramafic intrusions of the Giles Complex, western Musgrave Block, Western Australia. AGSO J Aust Geol Geophys 16:69-89

Barnes SJ (1986) The effect of trapped liquid crystallization on cumulus mineral compositions in layered intrusions. Contrib Mineral Petrol 93:524-531

Barnes SJ (1993) Partitioning of the platinum group elements and gold between silicate and sulphide magmas in the Munni Munni Complex, Western Australia. Geochim Cosmochim Acta 57:12771290
Barnes S-J, Lightfoot PC (2005) Formation of magmatic nickel sulfide ore deposits and processes affecting their copper and platinum group element contents. Econ Geol 100th Anniversary Volume:179-213

Barnes S-J, Maier WD (1999) The fractionation of Ni, Cu, and the noble metals in silicate and sulphide liquids. Geol Assoc Can Short Course Notes 13:69-106

Barnes S-J, Couture J-F, Sawyer EW, Bouchaib C (1993) Nickel-copper occurrences in the Belleterre-Angliers Belt of the Pontiac Subprovince and the use of $\mathrm{Cu}-\mathrm{Pd}$ ratios in interpreting platinumgroup element distributions. Econ Geol 88:1402-1418

Barnes S-J, Maier WD, Ashwal LD (2004) Platinum-group element distribution in the Main Zone and Upper Zone of the Bushveld Complex, South Africa. Chem Geol 208:293-317

Barrie CT, MacTavish AD, Walford PC, Chataway PC, Middaugh R (2002) Contact-type and magnetite reef-type $\mathrm{Pd}-\mathrm{Cu}$ mineralization in ferroan olivine gabbros of the Coldwell Complex, Ontario. In: Cabri LJ (ed) The geology, geochemistry, mineralogy and mineral beneficiation of platinum-group elements. Can Inst Min Metall Petrol Spec 54:321-337

Bushveld Minerals Ltd (2014) Bushveld Vanadium Project—scoping study results. Technical Report

Cameron EN (1980) Evolution of the Lower Critical Zone, central sector, eastern Bushveld Complex, and its chromite deposits. Econ Geol $75: 845-871$

Cawthorn RG, McCarthy TS (1980) Variations in Cr content of magnetite from the Upper Zone of the Bushveld Complex - evidence for heterogeneity and convection currents in magma chambers. Earth Planet Sci Lett 46:335-343

Cawthorn RG, Meyer FM (1993) Petrochemistry of the Okiep Cu district basic intrusive bodies, northwestern Cape province, South Africa. Econ Geol 88:590-605

Cawthorn RG, Eales HV, Walraven F, Uken R, Watkeys MK (2006) The Bushveld complex In: Johnson, MR, Anhaeusser, CR and Thomas, RJ (eds). The geology of South Africa. Geological Society of South Africa, Johannesburg, pp 261-281

Crawford A (2012) Petrographic report of 26 samples from Traka Resources Drillhole TMD002, W Musgraves, Western Australia for Anglo American Exploration (Australia)

Daniels JL (1974) Geology of the Blackstone Region. Western Australia Bull Geol Surv W Aust 123:257

Eales HV, Cawthorn RG (1996) The Bushveld Complex. In: Cawthorn RG (ed) Layered intrusions, developments in petrology, 15th edn. Elsevier, Amsterdam, pp 181-229

Ewart A, Griffin WL (1994) Application of proton-microprobe data to trace-element partitioning in volcanic rocks. Chem Geol 117:251284

Fandrich R, Gu Y, Burrows D, Moeller K (2007) Modern SEM-based mineral liberation analysis. Int J Miner Process 84:310-320

Geological Survey of Western Australia (2002) West Musgrave, W.A. Part sheets SG 52-5 and SG 52-6: total magnetic intensity image

Glikson AY, Ballhaus CG, Clarke GL et al (1995) Geological framework and crustal evolution of the Giles mafic-ultramafic complex and environs, western Musgrave Block, central Australia. AGSO J Aust Geol Geophys 16:41-67

Glikson AY, Stewart AT, Ballhaus CG, Clarke GL, Feeken EHT, Leven JH, Sheraton JW, Sun S-S (1996) Geology of the western Musgrave Block, central Australia, with particular reference to the mafic-ultramafic Giles Complex. AGSO Bull 239:206

Godel B, Seat Z, Maier WD, Barnes S-J (2011) The Nebo-Babel Ni-CuPGE sulfide deposit (West Musgrave Block, Australia): Pt. 2. Constraints on parental magma and processes, with implications for mineral exploration. Econ Geol 106:557-584

Goemann K (2012) Mineral liberation analysis for PGE phases, sample AUR101222. Central Science Laboratory, University of Tasmania, Hobart 
Goode ADT, Moore AC (1975) High pressure crystallization of the Ewarara, Kalka and Gosse Pile intrusions, Giles complex, central Australia. Contrib Mineral Petrol 51:77-97

Holwell DA, Keays RR (2014) The formation of low-volume, high-tenor magmatic PGE-Au sulfide mineralization in closed systems: evidence from precious and base metal geochemistry of the Platinova Reef, Skaergaard Intrusion, East Greenland. Econ Geol 109:387406

Howard HM, Smithies RH, Kirkland CL, Evins PM, Wingate MTD (2009) Age and geochemistry of the Alcurra Suite in the west Musgrave Province and implications for orthomagmatic $\mathrm{Ni}-\mathrm{Cu}-$ PGE mineralization during the Giles Event. Geol Surv W Aust, Record 2009/16

Howard HM, Smithies RH, Evins PM, Kirkland CL, Werner M, Wingate MTD, Pirajno F (2011a) Explanatory notes for the west Musgrave Province. Geol Surv W Aust, Record 2011/4

Howard HM, Werner M, Smithies RH, Kirkland CL, Kelsey DL, Hand M, Collins A, Pirajno F, Wingate MTD, Maier WD, Raimondo T (2011b) The geology of the west Musgrave Province and the Bentley Supergroup: a field guide. Geol Surv W Aust, Record 2011/4

Howard HM, Smithies RH, Kirkland CL, Kelsey DE, Aitken A, Wingate MTD, Quentin de Gromard R, Spaggiari CV, Maier WD (2015) The burning heart - the Proterozoic geology and geological evolution of the west Musgrave Region, central Australia. Gondwana Res 27:64 94

Irvine TN, Andersen JCØ, Brooks CK (1998) Included blocks (and blocks within blocks) in the Skaergaard intrusion: geologic relations and the origins of rhythmic modally graded layers. Geol Soc Am Bull 110:1398-1447

Joslin GD (2004) Stratiform palladium-platinum-gold mineralization in the Sonju Lake Intrusion, Lake County, Minnesota. Unpublished MSc thesis, University of Minnesota, Duluth, USA, $139 \mathrm{pp}$

Karykowski BT, Polito PA, Maier WD, Gutzmer J (2015) Origin of CuNi-PGE mineralization at the Manchego Prospect, West Musgrave Province, Western Australia. Econ Geol 110:2063-2085

Kirkland C, Wingate M, Smithies RH (2011) 194762: leucogabbro, Mount Finlayson. Geochronol Rec 966:4

Klemme S, Günther D, Hametner K, Prowatke S, Zack T (2006) The partitioning of trace elements between ilmenite, ulvospinel, armalcolite and silicate melts with implications for the early differentiation of the moon. Chem Geol 234:251-263

Le Maitre RW (ed) (2002) Igneous rocks: a classification and glossary of terms: recommendations of the international union of geological sciences subcommission on the systematics of igneous rocks. Cambridge University Press, pp 236

Leeman WP, Lindstrom DJ (1978) Partitioning of $\mathrm{Ni}^{2+}$ between basaltic and synthetic melts and olivines - an experimental study. Geochim Cosmochim Acta 42:801-816

Lipin BR (1993) Pressure increases, the formation of chromite seams, and the development of the ultramafic series in the Stillwater Complex, Montana. J Petrol 34:955-976

Liu PP, Zhou MF, Chen WT, Gao JF, Huang XW (2015) In-situ LA-ICPMS trace elemental analyses of magnetite: Fe-Ti-(V) oxide-bearing mafic-ultramafic layered intrusions of the Emeishan Large igneous Province, SW China. Ore Geol Rev 65:853-871

Maier WD (2000) Platinum-group elements in $\mathrm{Cu}$-sulphide ores at Carolusberg and East Okiep, Namaqualand, South Africa. Miner Deposita 35:422-429

Maier WD (2005) Platinum-group element (PGE) deposits and occurrences: mineralization styles, genetic concepts, and exploration criteria. J Afr Earth Sci 41:165-191

Maier WD, Barnes S-J, Gartz V, Andrews G (2003) Pt-Pd reefs in magnetitites of the Stella layered intrusion, South Africa: a world of new exploration opportunities for platinum group elements. Geology 31:885-888
Maier WD, Barnes SJ, Mungall JE (2005) Application of lithogeochemistry to exploration for PGE deposits. In: Mungall JE (ed) Exploration for platinum-group elements deposits. MAC Short Course Series 35:309-341

Maier WD, Barnes S-J, Groves DI (2013) The Bushveld Complex, South Africa: formation of platinum-palladium, chrome- and vanadiumrich layers via hydrodynamic sorting of a mobilized cumulate slurry in a large, relatively slowly cooling, subsiding magma chamber. Miner Deposita 48:1-56

Maier WD, Howard HM, Smithies RH, Yang S, Barnes S-J, O’Brien H, Huhma H, Gardoll S (2014) Mafic-ultramafic intrusions of the Giles Event, Western Australia: petrogenesis and prospectivity for magmatic ore deposits. Geol Surv W Aust, Report 134

Maier WD, Howard HM, Smithies RH, Yang SH, Barnes S-J, O’Brien H, Huhma H, Gardoll S (2015) Magmatic ore deposits in maficultramafic intrusions of the Giles Event, Western Australia. Ore Geol Rev 71:405-436

McDonough WF, Sun S-S (1995) The composition of the Earth. Chem Geol 120:223-253

Möbius ME, Lauderdale BE, Nagel SR, Jaeger HM (2001) Brazil-nut effect: size separation of granular particles. Nature 414:270-270

Mutanen T (1997) Geology and petrology of the Akanvaara and Koitelainen mafic layered intrusions and the Keivitsa-Satovaara layered complex, northern Finland. Geol Surv Finland Bull 395:233

Myers JS, Shaw RD, Tyler IM (1996) Tectonic evolution of Proterozoic Australia. Tectonics 15:1431-1446

Naldrett AJ, Wilson AH (1990) Horizontal and vertical variations in noble-metal distribution in the Great Dyke of Zimbabwe: a model for the origin of the PGE mineralization by fractional segregation of sulfide. Chem Geol 88:279-300

Naslund HR (1983) The effect of oxygen fugacity on liquid immiscibility in iron-bearing silicate melts. Am J Sci 283:1034-1059

Nesbitt RW, Talbot JL (1966) The layered basic and ultrabasic intrusives of the Giles Complex, central Australia. Contrib Mineral Petrol 13: $1-11$

Nesbitt RW, Goode ADT, Moore AC, Hopwood TP (1970) The Giles Complex, central Australia: a stratified sequence of mafic and ultramafic intrusions. Geol Soc South Afr Spec Publ 1:547-564

Osbahr I, Krause J, Bachmann K, Gutzmer J (2015) Efficient and accurate identification of platinum-group minerals by a combination of mineral liberation and electron probe microanalysis with a new approach to the offline overlap correction of platinum-group element concentrations. Microsc Microanal 21:1080-1095

PepinNini Minerals Ltd (2015) Spinifex range magnetics interpretation complete. ASX announcement

Prendergast MD (2000) Layering and precious metals mineralization in the Rincón del Tigre Complex, Eastern Bolivia. Econ Geol 95:113130

WMC Resources Ltd (2001) Combined annual report: C 231/1997

Roelofse F, Ashwal LD (2012) The lower main zone in the northern limb of the Bushveld Complex-a $>1.3 \mathrm{~km}$ thick sequence of intruded and variably contaminated crystal mushes. J Petrol 53:1449-1476

Sá JHS, Barnes S-J, Prichard HM, Fisher PC (2005) The distribution of base metals and platinum-group elements in magnetitite and its host rocks in the Rio Jacaré Intrusion, Northeastern Brazil. Econ Geol 100:333-348

Seat Z, Beresford SW, Grguric BA, Waugh RS, Hronsky JMA, Gee MAM, Groves DI, Mathison CI (2007) Architecture and emplacement of the Nebo-Babel gabbronorite-hosted magmatic Ni-Cu-PGE sulphide deposit, West Musgrave, Western Australia. Miner Deposita 42:551-581

Seat Z, Beresford SW, Grguric BA, Gee MAM, Grassineau NV (2009) Reevaluation of the role of external sulfur addition in the genesis of $\mathrm{Ni}-\mathrm{Cu}$-PGE deposits: evidence from the Nebo-Babel Ni-Cu-PGE Deposit, West Musgrave, Western Australia. Econ Geol 104:521-538 
Seat Z, Gee MAM, Grguric BA, Beresford SW, Grassineau NV (2011) The Nebo-Babel Ni-Cu-PGE sulfide deposit (West Musgrave, Australia): Pt. 1. U/Pb zircon ages, whole-rock and mineral chemistry, and O-Sr-Nd isotope compositions of the intrusion, with constraints on petrogenesis. Econ Geol 106:527-556

She YW, Song YX, Yu SY, He HL (2015) Variations of trace element concentration of magnetite and ilmenite from the Taihe layered intrusion, Emeishan large igneous province, SW China: implications for magmatic fractionation and origin of $\mathrm{Fe}-\mathrm{Ti}-\mathrm{V}$ oxide ore deposits. J Asian Earth Sci 113:1117-1131

Smithies RH, Howard HM, Evins PM, Kirkland CL, Bodorkos S and Wingate MTD (2008) The west Musgrave Complex-some new geological insights from recent mapping, geochronology, and geochemical studies. Geol Surv W Aust, Record 2008/19

Sun S-S, Sheraton JW, Glikson AY, Stewart AJ (1996) A major magmatic event during 1050-1080 Ma in central Australia, and an emplacement age for the Giles Complex. AGSO Res Newsl 24:13-15

Tegner C, Cawthorn RG, Kruger FJ (2006) Cyclicity in the main and upper zones of the Bushveld Complex, South Africa: crystallization from a zoned magma sheet. J Petrol 47:2257-2279

Teigler B, Eales HV (1996) The lower and critical zones of the western limb of the Bushveld Complex as intersected by the Nooitgedacht boreholes. Bull Geol Surv S Afr 111:126

Toplis MJ, Carroll MR (1996) Differentiation of ferro-basaltic magmas under conditions open and closed to oxygen: implications for the Skaergaard intrusion and other natural systems. J Petrol 37:837-858

Ulmer GC (1969) Experimental investigations of chromite spinels. Econ Geol Monogr 4:114-131
Veksler IV, Dorfman AM, Danyushevsky LV, Jakobsen JK, Dingwell DB (2006) Immiscible silicate liquid partition coefficients: implications for crystal-melt element partitioning and basalt petrogenesis. Contrib Mineral Petrol 152:685-702

Von Gruenewaldt G (1976) Sulfides in the upper zone of the eastern Bushveld Complex. Econ Geol 71:1324-1336

Wager LR, Brown GM (1968) Layered igneous rocks. Oliver \& Boyd, Edinburgh

Wills BA (2006) Mineral processing technology: an introduction to the practical aspects of ore treatment and mineral recovery. ButterworthHeinemann, London

Wilson AH, Tredoux M (1990) Lateral and vertical distribution of platinum-group elements and petrogenetic controls on the sulfide mineralization in the P1 pyroxenite layer of the Darwendale subchamber of the Great Dyke, Zimbabwe. Econ Geol 85: $556-584$

Wingate MTD, Pirajno F, Morris PA (2004) Warakurna large igneous province: a new Mesoproterozoic large igneous province in westcentral Australia. Geology 32:105-1081

Zhou M-F, Robinson PT, Lesher CM, Keays RR, Zhang CJ, Malpas J (2005) Geochemistry, petrogenesis and metallogenesis of the Panzhihua gabbroic layered intrusion and associated Fe-Ti-V oxide deposits, Sichuan Province, SW China. J Petrol 46:2253-2280

Zhou M-F, Chen WT, Wang CY, Prevec SA, Liu PP, Howarth GH (2013) Two stages of immiscible liquid separation in the formation of Panzhihua-type Fe-Ti-V oxide deposits, SW China. Geosci Front 4:481-502 